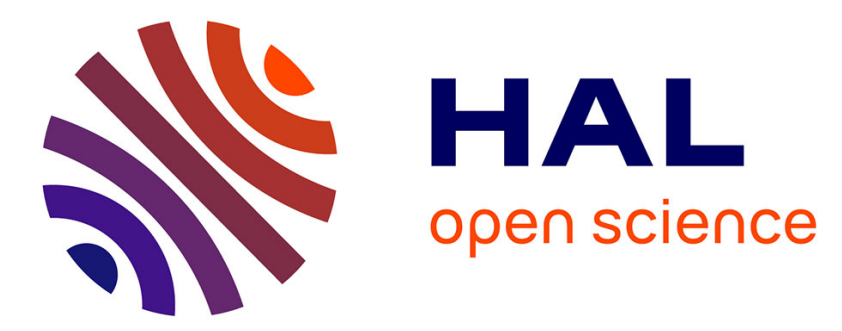

\title{
Transfer of persistent organic pollutants in food of animal origin - meta-analysis of published data
}

Farida Amutova, Matthieu Delannoy, Almagul Baubekova, Gaukhar

Konuspayeva, Stefan Jurjanz

\section{To cite this version:}

Farida Amutova, Matthieu Delannoy, Almagul Baubekova, Gaukhar Konuspayeva, Stefan Jurjanz. Transfer of persistent organic pollutants in food of animal origin - meta-analysis of published data. Chemosphere, 2021, 262, 10.1016/j.chemosphere.2020.128351 . hal-02937321v2

\section{HAL Id: hal-02937321 \\ https://hal.univ-lorraine.fr/hal-02937321v2}

Submitted on 29 Sep 2020

HAL is a multi-disciplinary open access archive for the deposit and dissemination of scientific research documents, whether they are published or not. The documents may come from teaching and research institutions in France or abroad, or from public or private research centers.
L'archive ouverte pluridisciplinaire HAL, est destinée au dépôt et à la diffusion de documents scientifiques de niveau recherche, publiés ou non, émanant des établissements d'enseignement et de recherche français ou étrangers, des laboratoires publics ou privés.

\section{(c)(1)}

Distributed under a Creative Commons Attribution| 4.0 International License 


\title{
Transfer of persistent organic pollutants in food of animal origin - meta-analysis of published data
}

\author{
Farida Amutovaa,b,c, Matthieu Delannoya , Almagul Baubekova ${ }^{d}$, Gaukhar \\ Konuspayeva ${ }^{\mathrm{c}, \mathrm{d}}$, Stefan Jurjanz ${ }^{\mathrm{a}^{*}}$.
}

\author{
a URAFPA, University of Lorraine-INRAe, 54500 Vandœuvre, France \\ ${ }^{b}$ Faculty of Geography and Environmental Sciences, Al-Farabi Kazakh National \\ University, 050040 Almaty, Kazakhstan
}

\section{c Antigen LLP, Scientific and Production Enterprise 040905, Almaty region, Kazakhstan}
${ }^{d}$ Faculty of Biology and Biotechnology, Al-Farabi Kazakh National University, 050040 Almaty, Kazakhstan

\section{Published in Chemosphere. Available online: 10.1016/..chemosphere.2020.128351}

\section{Highlights}

- High transfer and bioconcentration of the most toxic PCDD/Fs and PCBs

- PBDEs are less bioconcentrated than chlorinated POPs

- DDT congeners bioconcentrate easily but $\beta-\mathrm{HCH}$ does it more than the other isomers

- Transfer of chlorinated POPs in poultry seemed higher than in mammalians

\begin{abstract}
The transfer of POPs in food of animal origin has been studied by a meta-analysis of 28 peer-reviewed articles using transfer rate (TR) for milk and eggs and bioconcentration factors (BCF) for eligible tissues after establishing an adapted methodology. TRs of the most toxic PCDD/Fs into milk were generally elevated and even higher into eggs. BCFs in excreting adult animals varied widely between studies complicating to hierarchize tissues or congeners, even if liver and fat seemed to bioconcentrate more than lean tissues. Short time studies have clearly shown low BCFs contrarily to field studies showing the highest BCFs. The BCFs of PCDD/Fs in growing animals were higher in liver than in fat or muscle. In contrast to easily bioconcentrating hexachlorinated congeners, octa- and heptachlorinated congeners barely bioconcentrate. PCB transfer into milk and eggs was systematically high for very lipophilic congeners. Highly ortho-chlorinated PCBs were transferred $>50 \%$ into milk and eggs and even $>70 \%$ for congeners 123 and 167 into eggs. BCFs of the most toxic PCBs 126 and 169 were significantly higher than for less toxic congeners. BCFs seem generally low in PBDEs except congeners 47, 153 and 154. DDT and its metabolites showed high bioconcentration. Differences between tissues appeared but were masked by a study effect. In addition to some methodologic recommendations, this analysis showed the high transfer of POPs into eggs, milk and liver when animals were exposed justifying a strong monitoring in areas with POP exposure.
\end{abstract}

\section{Introduction}

Free-range agricultural animals ingest various environmental matrices as vegetation frequently used as feed, but also water or even soil. Several studies have reported that ruminants would consume in normal grazing conditions up to $10 \%$ of soil in daily dry matter intake (Healy, 1968; Jurjanz et al., 2012; Collas et al., 2019) and even up to 30\% in the worst conditions as winter grazing (Abrahams and Steigmajer, 2003). Poultry also ingest soil along pecking contaminated feed from the ground. In unbalanced feeding conditions, the soil intake in laying hens may reach up to $23 \%$ (Jondreville et al., 2010).

During such soil intake, persistent organic pollutants (POPs) deposited on the upper soil can be ingested by livestock (Fries et al., 1982; Jones et al., 1989; Stevens and Gerbec, 1988) and transferred into their subsequent food products. Previous studies have demonstrated that 
contaminated soil is the main source of exposure to pollutants for livestock, especially when soil is contaminated by lipophilic POPs, such us polychlorinated biphenyls (PCBs), dioxins and furans (PCDD/Fs) (Diletti et al., 2014), or organochlorinated pesticides (OCPs) (Tao et al., 2009). Some studies have reported transfers of OCPs and PCBs to livestock after atmospheric deposition leading to contamination of water, soil and vegetation (Pan et al., 2014) by regular floods (Abrahams and Steigmajer, 2003; Bryan, 2012) and others. Subsequently, POPs can be transferred to food of animal origin, such as milk, meat and eggs. As a result, consumption of such contaminated food would be a possible route of POP exposure for humans (McLachlan et al., 1990), and the correct quantification of the POP transfer from contaminated environmental matter to food products is essential for a reliable risk assessment.

Nevertheless, considerable variations can be found between reported transfers among different studies as they are based on different contamination matrices, doses and duration of exposure. However, such data are required to realize a risk assessment of food production systems. The aim of this paper was to derive and summarize current literature data on the transfer of different classes of POPs to edible tissues and food of animal origin. A consolidated methodology was used to discriminate the current knowledge about distribution and accumulation of PCDD/Fs, PCBs, PBDEs and OCPs in animal liver, fat and muscle tissue and their excretion into milk and eggs. At the end, this synthesis aims to improve monitoring system for livestock farming in contaminated areas.

\section{Materials and Methods:}

A database was created using peer-reviewed research articles reporting the transfer of POPs from ingested environmental matrices to edible tissues in different animal species (Table 1). Then, the transfer was evaluated by bioconcentration factors and transfer rates to characterize respectively the distribution of pollutants in tissues or the excretion of POPs via milk or eggs.

\section{Building-up the database}

In total, forty-one peer-reviewed articles reporting transfer of different POPs were browsed by Google Scholar through queries comprising the following keywords:
Excretion OR mass-balance OR carry-over rate OR transfer rate OR biotransfer AND (PCDD/F OR PCB OR OCP OR PBDE) AND ((milk AND ((cow OR cattle) OR (Goat OR Caprine))) OR (hens OR pig).

Transfer was quantified in two different concepts: as transfer rate (TR) when the target was excreted milk or eggs or as a bioconcentration factor (BCF) when transfer was measured via the enrichment in body tissues such as liver, muscles or body fat. Nevertheless, we did not integrate data of biotransfer factors (BTF), i.e. a ratio between tissue concentration and ingested amount of the studied POP. Although this approach would have several advantages, as the ingested amounts of all contaminated materials over the whole exposure period are required. These data are often missing due to field conditions and therefore not available for a risk assessment. As the concepts of TR and BCF were not used homogeneously in the literature, we firstly defined them.

The TR corresponds to the ratio between ingested and excreted amounts of the pollutant (equation 1) which can be calculated after reaching steady state (Richter and McLachlan, 2001) and expressed as a percentage:

$\mathrm{TR}_{\text {product }}=\frac{[\text { pollutant }]_{\mathrm{Fat} \text { of product }} * \text { Daily fat excretion }}{[\text { pollutant }]_{\text {Diet }} * \text { Diet Intake }} * 100 \%$

The [pollutant]fat of product corresponds to the concentration of pollutant in the fat of the food product (pg/g fat) and [pollutant]Diet to its concentration in the intake matrix feed or in soil (pg/g dry matter). Due to their lipophilicity, POP concentrations are commonly expressed in relation to fat content needing therefore information about fat mass of milk or eggs. Pollutants can also be accumulated in body tissues and reach concentrations higher than in the exposure matrix. The extent of this accumulation is expressed as the ratio between the concentrations in intake (i.e. feed or dry soil) and the studied body tissue (equation 2).

$\mathrm{BCF}=\frac{[\text { pollutant }]_{\text {tissue }}}{[\text { pollutant }]_{\text {intake }}}$

In this equation, [pollutant] tissue corresponds to the pollutant concentration in the tissues (pg/g fat) and [pollutant] feed to its concentration in feed (pg/g feed at $15 \%$ wet content) or in soil (pg/g dry matter). 
Table 1. Studies extracted from the literature, validation of the methodologic criteria and the decision of their integration in the data set.

\begin{tabular}{|c|c|c|c|c|c|c|c|c|c|c|c|c|c|c|}
\hline \multirow{2}{*}{ № } & \multirow{2}{*}{ Reference } & \multirow{2}{*}{\begin{tabular}{|c|}
$\begin{array}{c}\text { Studied } \\
\text { compound } \\
\mathbf{s}\end{array}$ \\
\end{tabular}} & \multirow{2}{*}{$\begin{array}{l}\text { Exposure } \\
\text { media }\end{array}$} & \multirow{2}{*}{$\begin{array}{l}\text { Category of } \\
\text { animals }\end{array}$} & \multirow{2}{*}{\begin{tabular}{|c|}
$\begin{array}{c}\text { Exposure } \\
\text { (days) }\end{array}$ \\
\end{tabular}} & \multirow{2}{*}{$\mathbf{S S}^{1}$} & \multirow{2}{*}{ Parameters $^{2}$} & \multicolumn{3}{|c|}{ Intake } & \multicolumn{3}{|c|}{ edible tissues } & \multirow{2}{*}{ Integration 5} \\
\hline & & & & & & & & $\mathrm{C}^{3}$ & $<\mathrm{LQ}^{4}$ & $Q^{3}$ & $\mathrm{C}^{3}$ & $<\mathrm{LQ}^{4}$ & $Q^{3}$ & \\
\hline \multirow{2}{*}{1} & \multirow{2}{*}{ Aulakh et al., 2006} & \multirow{2}{*}{ OCPs } & \multirow{2}{*}{ Feed } & \multirow{2}{*}{ Laying hens } & \multirow{2}{*}{\begin{tabular}{|c|}
$\begin{array}{c}\text { Field } \\
\text { exposure }\end{array}$ \\
\end{tabular}} & \multirow{2}{*}{$(\sqrt{ })$} & (BCF) & \multirow{2}{*}{$\checkmark$} & \multirow[t]{2}{*}{ 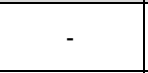 } & \multirow[b]{2}{*}{$(\sqrt{ })$} & \multirow{2}{*}{$\checkmark$} & \multirow{2}{*}{ - } & \multirow[b]{2}{*}{$\checkmark$} & $\checkmark$ \\
\hline & & & & & & & (TR) & & & & & & & $\checkmark$ \\
\hline 2 & Brambilla et al., 2008 & $\mathrm{PCDD} / \mathrm{Fs}$ & Minerals & Dairy cows & 28 & $(X)$ & TR & $x$ & - & $\checkmark$ & $x$ & - & $\checkmark$ & $\begin{array}{c}X \\
\text { (exposure }< \\
\text { half-live) }\end{array}$ \\
\hline 3 & Costera et al., 2006 & \begin{tabular}{|c|}
$\begin{array}{c}\text { PCDD/Fs, } \\
\text { PCBs }\end{array}$ \\
\end{tabular} & Hay & Dairy goats & 70 & $\checkmark$ & TR & $\checkmark$ & - & $\checkmark$ & $\checkmark$ & - & $\checkmark$ & $\checkmark$ \\
\hline 4 & Diletti et al., 2014 & $\begin{array}{c}\text { PCDD/Fs } \\
\text { PCBs }\end{array}$ & Feed & $\begin{array}{c}\text { dairy } \\
\text { buffaloes }\end{array}$ & 100 & $\checkmark$ & TR & $\checkmark$ & - & $\checkmark$ & $\checkmark$ & \begin{tabular}{|c|}
$2 \mathrm{PCDD} / \mathrm{Fs}$ \\
congeners out \\
of 17
\end{tabular} & $x$ & $\checkmark$ \\
\hline 5 & Feil et al.,2000 & PCDD/Fs & Feed & Cattle (calves) & 120 & $\checkmark$ & BCF & $\checkmark$ & - & $\checkmark$ & $\checkmark$ & $\begin{array}{c}8 \text { congeners out } \\
\text { of } 17\end{array}$ & - & $\begin{array}{c}X \\
\text { (C wet basis, } 8 \\
\text { congeners }<\text { LQ }\end{array}$ \\
\hline \multirow{3}{*}{6} & & & & Pigs & 81-179 & $(\checkmark)$ & BTF & $x$ & - & $x$ & $x$ & - & $x$ & \\
\hline & Fernandes et al., 2011 & $\begin{array}{l}\text { PCDD/Fs, } \\
\text { dl-PCBs }\end{array}$ & Feed & $\begin{array}{c}\text { Sheep (non lact. } \\
\text { ewes) }\end{array}$ & $48-153$ & $(\sqrt{ })$ & BTF & $x$ & - & $x$ & $x$ & - & $x$ & $\begin{array}{c}\hat{\wedge} \\
\text { (only BTF, }\end{array}$ \\
\hline & & & & $\begin{array}{c}\text { Broilers, } \\
\text { Laying hens } \\
\end{array}$ & $28-250$ & $(\sqrt{ })$ & BTF & $x$ & - & $x$ & $x$ & - & $x$ & \\
\hline 7 & Fournier et al., 2013 & iPCBs & Corn silage & goats & 39 & $\checkmark$ & MISS & $\checkmark$ & - & $\checkmark$ & $x$ & - & $\checkmark$ & $\begin{array}{c}X \text { (no reported } \\
\text { C in milk) } \\
\end{array}$ \\
\hline 8 & Fries et al., 1999 & $\mathrm{PCDD} / \mathrm{Fs}$ & $\begin{array}{l}\text { PCP-treated } \\
\text { Wood and } \\
\text { feed }\end{array}$ & dairy cows & 58 & $\checkmark$ & TR & $\checkmark$ & - & $\checkmark$ & $\checkmark$ & - & $\checkmark$ & 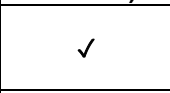 \\
\hline 9 & Fries et al., 2002 & $\mathrm{PCDD} / \mathrm{Fs}$ & Feed & dairy cows & 58 & $\checkmark$ & TR & $x$ & $\begin{array}{c}\text { congeners } \\
\text { out of } 17 \\
\end{array}$ & $\checkmark$ & $x$ & $\begin{array}{c}3 \text { congeners or } \\
\text { of } 17\end{array}$ & $x$ & $\checkmark$ \\
\hline & & $\begin{array}{l}\text { PCDD/Fs } \\
\text { PCBs }\end{array}$ & Feed & Broilers & 7 & $x$ & $\mathrm{BCF}$ & $\checkmark$ & - & $\checkmark$ & $\checkmark$ & $\begin{array}{c}3 \mathrm{PCDD} / \mathrm{Fs} \\
\text { congeners out } \\
\text { of } 17\end{array}$ & $x$ & $\checkmark$ \\
\hline 10 & Hoogenboom et al., 2004 & $\begin{array}{c}\text { PCDD/Fs } \\
\text { PCBs }\end{array}$ & Feed & Pigs & 7 & $x$ & BCF & $\checkmark$ & - & $\checkmark$ & $\checkmark$ & $\begin{array}{c}3 \mathrm{PCDD} / \mathrm{Fs} \\
\text { congeners out } \\
\text { of } 17\end{array}$ & $x$ & $\checkmark$ \\
\hline 11 & Hoogenboom et al., 2006 & PCDD/Fs & Feed & Laying hens & 56 & $\checkmark$ & TR & $\checkmark$ & - & $\checkmark$ & $\checkmark$ & - & $\checkmark$ & $\checkmark$ \\
\hline 12 & & PCDD/Fs & $\begin{array}{c}\text { Maize silage or } \\
\text { sugar beet }\end{array}$ & dairy cows & 33 & $(X)$ & TR & $\checkmark$ & - & $\checkmark$ & $\checkmark$ & $\begin{array}{c}9 \text { congeners out } \\
\text { of } 17\end{array}$ & $\checkmark$ & $\begin{array}{c}X \\
\text { (exposure } \\
\text { <half-live) } \\
\end{array}$ \\
\hline 12 & (a) & PCBs & $\begin{array}{c}\text { Maize silage or } \\
\text { sugar beet }\end{array}$ & dairy cows & 33 & $(\sqrt{ })$ & TR & $\checkmark$ & $\begin{array}{c}7 \text { congeners } \\
\text { out of } 12\end{array}$ & $\checkmark$ & $\checkmark$ & $\begin{array}{c}4 \text { congeners out } \\
\text { of } 12\end{array}$ & $\checkmark$ & $\checkmark$ \\
\hline 13 & $\begin{array}{l}\text { Hoogenboom } \\
\text { et al., } 2015 \text { (b) }\end{array}$ & $\begin{array}{c}\text { PCDD/Fs, } \\
\text { PCBs }\end{array}$ & Grass & Lamb & 113 & $(\sqrt{ })$ & (BCF) & $\checkmark$ & $\begin{array}{l}1 \text { congener } \\
\text { out of } 17\end{array}$ & $\checkmark$ & $\checkmark$ & $\begin{array}{c}2 \text { congeners out } \\
\text { of } 17\end{array}$ & $x$ & $\checkmark$ \\
\hline 14 & $\begin{array}{c}\text { Huwe } \\
\text { et al., } 2005\end{array}$ & $\begin{array}{l}\text { PCDD/Fs } \\
\text { dl-PCBs }\end{array}$ & Mineral Mix & dairy cows & $\begin{array}{l}\text { Averaged } \\
\text { between } \\
17\end{array}$ & $\checkmark$ & TR & $\checkmark$ & $\begin{array}{c}3 \text { congeners } \\
\text { out of } 17\end{array}$ & $\checkmark$ & $\checkmark$ & - & $\checkmark$ & $\begin{array}{c} \\
\text { (exposure } \\
<\text { half-live) } \\
\end{array}$ \\
\hline & & & & & & & $\mathrm{BCF}$ & & & & & & & $\checkmark$ \\
\hline 15 & $\begin{array}{c}\text { Kerst } \\
\text { et al., } 2004\end{array}$ & dl-PCBs & Grass & dairy cows & \begin{tabular}{|c|}
$\begin{array}{c}\text { Field } \\
\text { exposure }\end{array}$ \\
\end{tabular} & $(\sqrt{ })$ & TR & $\checkmark$ & - & $\checkmark$ & $\checkmark$ & - & $\checkmark$ & $\checkmark$ \\
\hline 16 & $\begin{array}{l}\text { Kiergaard } \\
\text { et al., } 2009\end{array}$ & PBDE & Feed & dairy cows & 90 & $\checkmark$ & (BCF) & $(\sqrt{ })$ & - & $\checkmark$ & $(\checkmark)$ & - & $\checkmark$ & $\checkmark$ \\
\hline 17 & $\begin{array}{l}\text { Lorenzi } \\
\text { et al., } 2020\end{array}$ & \begin{tabular}{|c|} 
PCDD/Fs, \\
dl and \\
iPCBs \\
\end{tabular} & Feed & dairy cows & 49 & $\checkmark$ & TR & $\checkmark$ & - & $\checkmark$ & $\checkmark$ & - & $\checkmark$ & $\checkmark$ \\
\hline 18 & $\begin{array}{l}\text { McLachlan } \\
\text { et al., } 1990\end{array}$ & PCDD/Fs & Feed & dairy cows & 35 & $x$ & TR & $x$ & - & $\checkmark$ & $x$ & - & $\checkmark$ & $\begin{array}{c}\quad \mathrm{X} \\
\text { (exposure } \\
\text { <half-live) }\end{array}$ \\
\hline & & $\mathrm{PCDD} / \mathrm{Fs}$ & Feed & dairy cows & 84 & $(\sqrt{ })$ & TR & $\checkmark$ & - & $\checkmark$ & $x^{2}$ & $\begin{array}{c}4 \text { congeners out } \\
\text { of } 17\end{array}$ & $\checkmark$ & $\checkmark$ \\
\hline 19 & $\begin{array}{l}\text { McLachlan and } \\
\text { Richter,1998 }\end{array}$ & PCDD/Fs & Feed & dairy cows & 23 & $(X)$ & TR & $\checkmark$ & - & $\checkmark$ & $x^{2}$ & $\begin{array}{c}2 \text { congeners out } \\
\text { of } 17\end{array}$ & $\checkmark$ & $\begin{array}{c}\quad x \\
\text { (exposure } \\
\text { <half-live) }\end{array}$ \\
\hline 20 & $\begin{array}{l}\text { Malisch } \\
\text { et al., } 2000\end{array}$ & PCDD/Fs & Citrus pulp & dairy cows & 180 & $(\sqrt{ })$ & TR & $x$ & - & $\checkmark$ & $\checkmark$ & $\begin{array}{l}1 \text { congener } \\
\text { out of } 17\end{array}$ & $x$ & $\checkmark$ \\
\hline 21 & $\begin{array}{l}\text { Olling } \\
\text { et al., } 1991\end{array}$ & PCDD/Fs & $\begin{array}{c}\text { Intraruminally } \\
\text { dose in oil }\end{array}$ & dairy cows & $\begin{array}{c}1 \\
\text { (single dos }\end{array}$ & $x$ & TR & $x$ & - & $\checkmark$ & $\checkmark$ & - & $\checkmark$ & $\begin{array}{c}X \\
\text { (Single dose } \\
\text { exposure) }\end{array}$ \\
\hline 22 & Ounnas et al., 2010 & \begin{tabular}{|c|} 
PCBs (dl \& \\
mono- \\
ortho), \\
PBDE \\
\end{tabular} & Soil & goats & 80 & $\checkmark$ & $\begin{array}{c}\text { TR } \\
\text { BCF }\end{array}$ & $\checkmark$ & - & $\checkmark$ & $\checkmark$ & - & $\checkmark$ & $\checkmark$ \\
\hline 23 & Pan et al., 2014 & $\begin{array}{l}\text { OCPs } \\
\text { iPCBs }\end{array}$ & Grass & yak & \begin{tabular}{|c|} 
Field \\
exposure
\end{tabular} & $(\sqrt{ })$ & (BCF) & $\checkmark$ & - & $x$ & $\checkmark$ & - & $x$ & $\checkmark$ \\
\hline 24 & Parera et al., 2008 & $\mathrm{PCDD} / \mathrm{Fs}$ & Feed & Broilers & 39 & - & $(\mathrm{BCF})$ & $\checkmark$ & - & $\checkmark$ & $\checkmark$ & $\begin{array}{c}2 \text { congeners or } \\
\text { of } 17\end{array}$ & - & $\checkmark$ \\
\hline
\end{tabular}




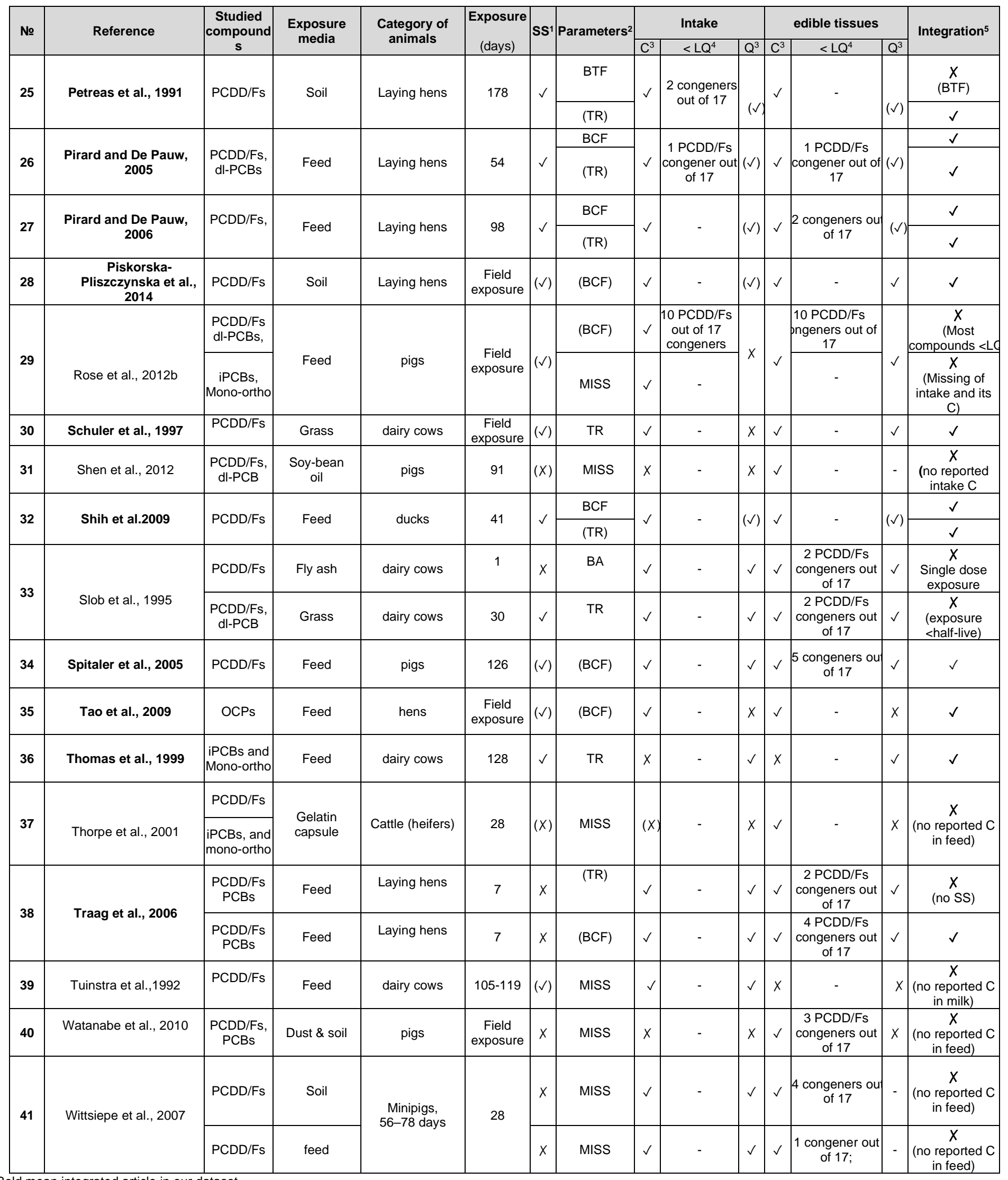

Bold mean integrated article in our dataset

${ }^{1}$ Statement of steady state (SS) given by the authors or in brackets when statement was made by us.

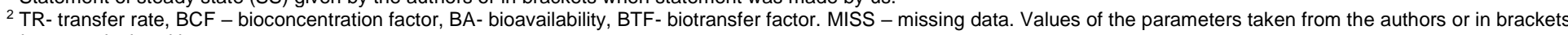
when re-calculated by us.

${ }^{3} \mathrm{C}$ - concentrations, Q-quantities where $\checkmark=$ given in the article; $(\checkmark)=$ Recalculated; $X=$ not available

${ }^{4}$ Compounds that below limit of quantification (LQ)

${ }^{5}$ Decision of integration $(\checkmark)$ or not $(X)$ of the given study in our dataset 


\section{Selection criterion of articles in the dataset}

A calculation of transfer rate was conditioned by the duration of exposure which would allow the considered compound to reach in the tissue of the exposed animal a stable concentration of steady state (Huwe and Smith, 2005; Ounnas et al., 2010). Casarett and Doull (2008) defined the steady state as the physiological state of animal during a continuous exposure to a fixed daily dose, leading to a concentration remaining stable in time. Therefore, the compound specific exposure duration is the key parameter to achieve a steady state plateau.

We considered that steady state conditions have been reached when authors reported it clearly in their article. If not, we evaluated the exposure duration in comparison to the half-life of the considered compound in the given animal type (mammalians versus birds) in respect to its life expectancy. For example, half-life of PCDD/Fs in hen eggs is 30 days (Petreas et al., 1991), but would be more than 40 days in cow milk (Olling et al., 1991; Huwe et al., 2005) and goat milk (Costera et al., 2006). Contrarily, half-life of PCBs in hen eggs and goat milk of only 30 days has been confirmed by averaged results of Hoogenboom et al. (2015a) and Costera et al. (2006) respectively. Indeed, halflife of the target compound would allow to predict the necessary exposure duration to reach steady state (Holford, 2012): $50 \%$ of the steady state concentration would be reached after one half-life and $87,6 \%$ after three half-lives. We fixed an acceptable level of steady state at $90 \%$ of the plateau corresponding to 3.3 half- lives of the considered compound. The study of Hoogenboom et al. (2006) on laying hens reported the transfer of different POPs in eggs after exposure durations of 56 days, declared as "close to steady state plateau". By acceptation, this study has been integrated in the dataset. Furthermore, some studies have reported exposure due to a field contamination (i.e. long-time exposure of several weeks, often several months) for dairy cows (Kerst et al., 2004, Schuler et al., 1997) or laying hens (Aulakh et al., 2006, PiskorskaPliszczynska et al., 2014). These studies were also integrated in our dataset considering that these animals had probably be exposed long enough to the studied compounds that makes the achievement of a steady state plateau likely.

In contrast to transfer studies into milk or eggs, the achievement of a steady state was not a selection criterion to integrate studies reporting BCFs.
Indeed, the target animals were generally meatproducing categories such as pigs, broilers or, lambs. Their rapid increase in body mass will constantly redistribute target substances in tissues that makes the achievement of a stable concentration nearly impossible. In other words, the steady state could only be achieved in adults with a stable body weight. Therefore, we compared BCFs between two groups of animals: firstly, excreting adults (lactating mammalians or laying birds) or secondly, rapidly growing young animals, generally raised for meat production. Then comparisons were carried out on BCFs issued from the same study: either the different congeners within the same tissue or the different tissues for given congener. Finally, the interpretation of BCFs will distinguish short time exposure ( $\leq 7$ days) but no single dose and chronic exposure (clearly more than 7 days).

Except some minor adaptions of the expression (i.e. equations 1 and 2), we used generally TRs and BCFs as they were indicated in the article. In absence of reported TR or BCFs we calculated them ourselves using the data reported in the article. However, some studies needed some zootechnical hypothesis to calculate TRs or BCFs:

1) Some studies have reported only concentrations in feed and tissues (Traag et al., 2006, Huwe et al., 2005, Parera et al., 2008, Tao et al., 2009 and Kiergaard et al., 2009, Hoogenboom et al., 2015b) that we used to calculate BCFs.

2) In absence of any specification in the article, we evaluated the daily feed intake of laying hens as $110 \mathrm{~g}$ (studies of Petreas et al 1991; Pirard and De Pauw 2005). If missing, the output of very lipophilic POPs by laying hens has been evaluated on the basis of a standard egg ( $55 \mathrm{~g}$ containing $27 \%$ lipids in the yolk) enhancing a fat excretion of $5.4 \mathrm{~g}$ per egg. The laying productivity in intensive free-range rearing conditions of 6 eggs per week was supposed leading to an average daily fat excretion of $4.6 \mathrm{~g} / \mathrm{day}$ via egg laying. In addition, Petreas et al. (1991) reported TRs of PCDD/Fs in eggs in a study where $10 \%$ of contaminated soil was integrated in the feed. Therefore, we considered a global intake of $99 \mathrm{~g}$ of feed and $11 \mathrm{~g}$ of (contaminated) soil to establish the global intake concentration of the contaminants.

3) Shih et al. (2009) investigated the transfer of PCDD/Fs into eggs of laying ducks. The contaminants were issued from dust of which $0,6 \%$ was integrated in their feed. According to Bley et al. (2008), a daily feed intake of $200 \mathrm{~g}$ was supposed 
and then the daily dust intake would represent 1.2 g. The fat excretion in duck eggs has been supposed to be $7.5 \mathrm{~g}$ daily (laying productivity of $90 \%$ for eggs of $66 \mathrm{~g}$ containing $8.3 \mathrm{~g}$ of yolk fat; Kaewmanee et al., 2011).

4) The field study of Piskorska-Pliszczynska et al. (2014) considered soil as the only source of PCDD/Fs. Aiming to obtain a reliable concentration in the global intake for BCF calculations, we divided the ingested amounts of contaminants by an estimated amount of ingested matter, i.e. $90 \mathrm{~g}$ of feed and $20 \mathrm{~g}$ of soil in free range laying hens as reported by Jondreville et al. (2010).

5) The study on yaks (Pan et al., 2014) allowed calculations of BCFs between grass and the tissues muscle and liver considering grass as the only exposure source. Nevertheless, notable differences in POP concentrations had been shown between summer and winter samples. Therefore, the average concentration in tissues has been used. In absence of consolidated data about feed intake or milk yields of these yaks, we renounced to calculate TRs in milk.

6) Aulakh et al. (2006) presented an original field study reporting concentration of different OCPs in feed, eggs and muscles of hens. TR to eggs was calculated using the same feed intake and egg composition than previously presented. The calculation of BCFs in hen muscle was based on a fat content of $10 \%$ in the fresh matter according to Kaewkot et al. (2020).

Thus, table 1 shows the complete list of extracted articles, the studied compounds, species, exposure duration and the integration choices. Thirteen research papers out of 41 have not been integrated and 2 only partly, mainly due to a too short exposure duration of the animals (in case of TRs), which not allowed to achieve steady state conditions (Brambilla et al., 2008; Olling et al., 1991; Huwe et al., 2005; Slob et al., 1995; Traag et al., 2006; McLachlan et al., 1990). In addition, there are missing intake and/or tissue concentrations for calculation of BCFs in the studies of Fernandes et al. (2011), Fournier et al. (2013), Shen et al. (2012), Thorpe et al. (2001), Tuinstra et al. (1992), Watanabe et al. (2010) and Wittsiepe et al. (2007). Finally, the studies of Feil et al. (2000) and Rose et al. (2012) reported transfer of PCDD/Fs and PCBs from feeds but the concentrations of the studied POPs are generally under the limit of quantification.

\section{Data analysis}

Transfer rates

After extraction of TRs values from the relevant studies, a mean and a SD were calculated for each congener in a given product (i.e. milk or egg). Based on these values, the transfer was classified in four levels depending on the TR:

- high transfer when TR>25\%;

- medium transfer for TRs between 10 and 25\%;

- low transfer when TR is between 0.5 and up to $10 \%$ and

- no significant transfer was considered when TRs were $<0.5 \%$.

The comparison between the different congeners of PCDD/Fs (table 2) and PCBs (table 3) was based on the one hand on the differences between mean TRs weighed by the associated SDs and on the other hand on the attributed transfer levels.

Additionally, two separate principal component analysis (PCA) were carried out respectively for milk and eggs using the software XLSTAT 2020 (Addinsoft Corp., New York, USA) to illustrate the link between TRs and some chemical characteristics of the PCB congeners (Log KOW, $\mathrm{MW}$, number of chlorines $\mathrm{Cln}$, ortho-substitution). The variable TR being the variable to be explained was added as a supplementary variable (Joliffe and Penny, 2002).

\section{Bioconcentration Factors}

The BCFs derived from the relevant papers were summarized in tables depending on the chemical family (i.e. PCDD/Fs, PCBs, PBDEs and OCPs). Within each table, the BCFs per congener and tissue were listed. Tissues were inventoried in the tables in a decreasing order of mean BCFs over all integrated studies.

Then, BCFs for PCDD/Fs were divided in two animal categories and presented separately:

- Adult animals with depuration excretion (i.e. lactating mammalians or laying birds) (table 4 grouping the data issued from the studies of Huwe et al., 2005; Pirard and De Pauw, 2005; Pirard and De Pauw, 2006; Traag et al., 2006; Shih et al., 2009; and Piskorska-Pliszczynska et al., 2014).

- Rapidly growing young animals, generally raised for meat purposes (broilers, pigs and lambs) (table 5 grouping data from the studies of 
Table 2. Transfer of PCDD/Fs in milk and eggs expressed as TR (mean and SD) and transfer level, depending on the congener, its chemical characteristics (number of chlorines $\left(\mathrm{Cl}_{n}\right)$, Log of the partition coefficient octanol/water (log $\mathrm{K}_{\mathrm{ow}}$ ), molecular weight $\left.(\mathrm{MW})\right)$ and Toxic Equivalency Factors (TEF).

\begin{tabular}{|c|c|c|c|c|c|c|c|c|c|}
\hline \multirow[t]{2}{*}{ Compound } & \multirow{2}{*}{$\begin{array}{c}\text { TEF } \\
\left(\mathrm{WHO}_{05}\right)\end{array}$} & \multicolumn{3}{|c|}{ Chemical characteristics } & \multicolumn{2}{|c|}{ Transfer to milk } & \multicolumn{2}{|c|}{ Transfer to hen eggs } & \multirow{2}{*}{$\begin{array}{l}\text { Transfer to } \\
\text { duck eggs } \\
T^{4}, \%(n=1)\end{array}$} \\
\hline & & $\mathrm{Cl}_{\mathrm{n}}$ & Log $\mathrm{K}_{\text {ow }}{ }^{1}$ & MW & $\mathrm{TR}^{2}, \%(\mathrm{n}=8)$ & Level $^{3}$ & $\mathrm{TR}, \%(\mathrm{n}=4)$ & Level & \\
\hline 2,3,7,8-TCDD & 1 & 4 & 6.6 & 322 & $34.0 \pm 6.3$ & High & $39.1 \pm 12.6$ & High & 2.0 \\
\hline 1,2,3,7,8 -PeCDD & 1 & 5 & 7.2 & 340 & $26.7 \pm 7.1$ & High & $35.8 \pm 12.2$ & High & 3.4 \\
\hline $1,2,3,4,7,8-\mathrm{H} \times \mathrm{CDD}$ & 0.1 & 6 & 7.6 & 391 & $17.8 \pm 8.0$ & Medium & $43.3 \pm 16.5$ & High & 2.3 \\
\hline $1,2,3,6,7,8-\mathrm{H} \times \mathrm{CDD}$ & 0.1 & 6 & 7.6 & 391 & $22.7 \pm 7.1$ & Medium & $40.6 \pm 14.4$ & High & 3.0 \\
\hline $1,2,3,7,8,9-\mathrm{HxCDD}$ & 0.1 & 6 & 7.6 & 391 & $13.2 \pm 3.4$ & Medium & $29.1 \pm 12.4$ & High & 1.3 \\
\hline $1,2,3,4,6,7,8-\mathrm{HpCDD}$ & 0.01 & 7 & 8.0 & 425 & $4.1 \pm 1.3$ & Low & $16.2 \pm 6.2$ & Medium & 1.1 \\
\hline OCDD & 0.0003 & 8 & 8.4 & 460 & $1.2 \pm 0.8$ & Low & $6.8 \pm 4.8$ & Low & 1.0 \\
\hline 2,3,7,8-TCDF & 0.1 & 4 & 6.5 & 306 & $3.4 \pm 2.9$ & Low & $39.1 \pm 16.8$ & High & 6.4 \\
\hline $1,2,3,7,8-\mathrm{PeCDF}$ & 0.03 & 5 & 7.0 & 340 & $4.9 \pm 4.5$ & Low & $38.0 \pm 7.4$ & High & 4.5 \\
\hline 2,3,4,7,8-PeCDF & 0.3 & 5 & 7.1 & 340 & $35.6 \pm 14.8$ & High & $40.0 \pm 10.1$ & High & 4.8 \\
\hline $1,2,3,4,7,8-\mathrm{H} \times C D F$ & 0.1 & 6 & 7.5 & 375 & $19.3 \pm 8.9$ & Medium & $39.8 \pm 13.0$ & High & 2.5 \\
\hline $1,2,3,6,7,8-\mathrm{H} \times \mathrm{CDF}$ & 0.1 & 6 & 7.6 & 375 & $17.7 \pm 6.0$ & Medium & $37.3 \pm 16.1$ & High & 2.4 \\
\hline $1,2,3,7,8,9-\mathrm{HxCDF}$ & 0.1 & 6 & 7.7 & 375 & $10.7 \pm 7.0$ & Medium & $25.6 \pm 13.0$ & High & 1.9 \\
\hline $2,3,4,6,7,8-\mathrm{H} \times \mathrm{CDF}$ & 0.1 & 6 & 7.6 & 375 & $11.6 \pm 8.7$ & Medium & $23.0 \pm 16.5$ & Medium & 0.8 \\
\hline $1,2,3,4,6,7,8-\mathrm{HpCDF}$ & 0.01 & 7 & 8.0 & 409 & $3.1 \pm 1.1$ & Low & $16.6 \pm 10.7$ & Medium & 0.7 \\
\hline $1,2,3,4,7,8,9-\mathrm{HpCDF}$ & 0.01 & 7 & 8.2 & 409 & $4.6 \pm 1.3$ & Low & $17.8 \pm 8.7$ & Medium & 1.1 \\
\hline OCDF & 0.0003 & 8 & 8.6 & 443 & $1.0 \pm 1.3$ & Low & $4.0 \pm 2.5$ & Low & 0.1 \\
\hline
\end{tabular}

Bold values are highly transferred

$1 \log$ Kow for PCDDs and PCDFs were taken from Chen et al., 2001 and Govers and Krop, 1998 respectively.

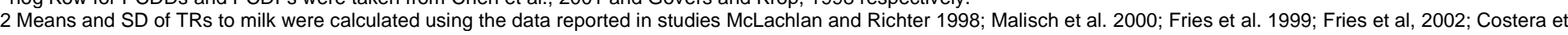
al. 2006, Lorenzi et al. 2020, Diletti et al. 2014 ; Schuler et al., 1997.

3 Means and SD of TRs to eggs were calculated using the data of the 2 treatments reported by Hoogenboom et al. 2006; Petreas et al.,1991; Pirard and de Pauw, 2005; Pirard and de Pauw, 2006.

4Transfer to duck eggs based on Shih et al., 2009, level of transfer is low for all congeners.

Hoogenboom et al., 2004; Spitaler et al., 2005; Results

Parera et al., 2008; and Hoogenboom et al., 2015b).

The size of the dataset for PCBs, PBDEs or OCPs did not allow such a distinction for the presentation of their data. BCFs for PCBs were grouped in one synthetic table (table 6) for both groups of animals. Nevertheless, the mention of the animal type and the duration allowed the comparison of BCFs between tissues or between congeners. Finally, sparser data of PBDEs (2 studies) and OCPs (3 studies) were simply listed by tissues and by congeners in a synthetic table (respectively 7 and 8). By the way, the analysis of PBDEs was restricted by numerous tissue concentrations under the $L Q$.

A statistical comparison of BCFs appeared irrelevant due to the differences between the grouped studies, especially on exposure duration and doses. Therefore, the comparisons were built on the hierarchy of the distribution within a given study on the one hand between the different congeners and on the other hand between the different tissues to generalize pathways of bioconcentration mechanisms.

\section{Transfer into milk and eggs (TRs)}

\section{$P C D D / F s$}

The TRs of PCDD/F congeners (means and standard deviations) into milk and eggs were presented together with the associated transfer levels, their toxicity (TEF) as well as their chemical characteristics $\mathrm{Cln}$, log Kow, substitution type and MW in table 2.

Generally, all studied PCDD/Fs congeners were transferred to milk or eggs at a very variable degree. Unfortunately, the most toxic compounds (i.e. TCDD and 1,2,3,7,8-PeCDD) showed the highest transfer to these food products with over $26 \%$ and over $35 \%$ for milk and eggs respectively (table 2). Hexachlorinated dioxins had a medium transfer level to milk (13-23\%) but were highly transferred to eggs (29-43\%). Hepta- and octachlorinated dioxins were generally transferred at a low level, but always less in milk $(<4 \%)$ than in eggs $(7-16 \%)$ (table 2$)$. Also for PCDFs, transfer to eggs is generally higher than to milk. Tetra- and pentachlorinated furans had highest TR levels in eggs (i.e. $38 \%$ to $40 \%$ ) but not 
Table 3. Transfer of PCBs in milk and eggs expressed as TR (mean and SD) and transfer level, depending on the congener, its Toxic Equivalency Factors (TEF) and its chemical characteristics number of chlorines $\left(\mathrm{Cl}_{n}\right)$, Log of the partition coefficient octanol/water $\left(\log \mathrm{K}_{\mathrm{ow}}\right)$, molecular weight $(\mathrm{MW})$ and the substitution.

\begin{tabular}{|c|c|c|c|c|c|c|c|c|c|c|c|}
\hline \multirow{2}{*}{$\begin{array}{l}\text { PCB } \\
\text { No }\end{array}$} & \multirow{2}{*}{$\begin{array}{c}\text { TEF } \\
\left(\mathrm{WHO}_{05}\right)\end{array}$} & \multicolumn{4}{|c|}{ Chemical characteristics } & \multicolumn{3}{|c|}{ Transfer to milk } & \multicolumn{3}{|c|}{ Transfer to hen eggs } \\
\hline & & $\mathrm{Cln}_{\mathrm{n}}$ & $\begin{array}{l}\text { Log } \\
\text { Kow }^{1}\end{array}$ & MW & $\begin{array}{c}\text { Substitution } \\
\text { type }\end{array}$ & $\mathrm{TR}^{2}, \%$ & level & $\mathrm{n}$ & $\mathrm{TR}^{3}, \%$ & level & $\mathrm{n}$ \\
\hline 28 & nd & 3 & 5.6 & 257 & mono-ortho & $9.4 \pm 12.8$ & medium & 7 & $40.5 \pm 3.5$ & high & 2 \\
\hline 52 & nd & 3 & 5.8 & 292 & di-ortho & $3.8 \pm 5.4$ & low & 6 & $4.5 \pm 0.7$ & low & 2 \\
\hline 77 & 0.0001 & 4 & 6.4 & 292 & non-ortho & $5.5 \pm 4.3$ & low & 7 & $32.6 \pm 25.9$ & high & 3 \\
\hline 81 & 0.0003 & 4 & 6.4 & 292 & non-ortho & $12.5 \pm 6.0$ & medium & 6 & $30.2 \pm 17.8$ & high & 3 \\
\hline 101 & nd & 5 & 6.3 & 326 & di-ortho & $4.8 \pm 1.3$ & low & 6 & 5.0 & low & 2 \\
\hline 105 & 0.00003 & 5 & 6.6 & 326 & mono-ortho & $50.0 \pm 33.4$ & high & 4 & $49.0 \pm 4.2$ & high & 2 \\
\hline 114 & 0.00003 & 5 & 6.6 & 326 & mono-ortho & $51.8 \pm 16.2$ & high & 6 & $51.5 \pm 0.7$ & high & 2 \\
\hline 118 & 0.00003 & 5 & 6.7 & 326 & mono-ortho & $77.8 \pm 45.1$ & high & 5 & $50.0 \pm 2.8$ & high & 2 \\
\hline 123 & 0.00003 & 5 & 6.7 & 326 & mono-ortho & $22.2 \pm 10.6$ & medium & 6 & $74.0 \pm 5.7$ & high & 2 \\
\hline 126 & 0.1 & 5 & 7.0 & 326 & non-ortho & $40.2 \pm 11.4$ & high & 5 & $37.7 \pm 19.6$ & high & 3 \\
\hline 138 & nd & 6 & 6.7 & 361 & di-ortho & $46.1 \pm 19.0$ & high & 6 & $52.5 \pm 2.1$ & high & 2 \\
\hline 153 & nd & 6 & 6.8 & 361 & di-ortho & $54.1 \pm 25.1$ & high & 4 & $59.0 \pm 2.8$ & high & 2 \\
\hline 156 & 0.00003 & 6 & 7.1 & 361 & mono-ortho & $64.1 \pm 26.3$ & high & 3 & $56.5 \pm 2.1$ & high & 2 \\
\hline 157 & 0.00003 & 6 & 7.1 & 361 & mono-ortho & $50.5 \pm 21.5$ & high & 3 & $58.0 \pm 9.9$ & high & 2 \\
\hline 167 & 0.00003 & 6 & 7.2 & 361 & mono-ortho & $58.1 \pm 25.3$ & high & 3 & $80.0 \pm 5.7$ & high & 2 \\
\hline 169 & 0.03 & 6 & 7.5 & 361 & non-ortho & $40.3 \pm 8.0$ & high & 4 & $39.5 \pm 19.9$ & high & 3 \\
\hline 180 & nd & 7 & 7.2 & 395 & di-ortho & $51.8 \pm 17.7$ & high & 3 & $\mathbf{5 0 . 0} \pm 12.7$ & high & 2 \\
\hline 189 & 0.00003 & 7 & 7.6 & 395 & mono-ortho & $38.0 \pm 23.2$ & high & 3 & 61.0 & high & 2 \\
\hline
\end{tabular}

Bold values are highly transferred

nd: not determined

1 Log Kow taken from Zhou et al. 2005

2 Means and SD of TRs to milk were calculated using the data reported in studies Costera et al.,2006; Thomas et al.,1999; Ounnas et al., 2010; Lorenzi et al., 2020; Kerst et al.,

2004; Diletty et al.,2014; Hoogenboom et al., 2015 (a).

3 Means and SD of TRs to eggs were calculated using the data of the 2 treatments reported by Hoogenboom et al 2006; and Pirard and de Pauw, 2005

in milk where only 2,3,4,7,8-PeCDF had a TRs of congeners (i.e. log Kow > 6.5) presented high TRs over $35 \%$. Nevertheless, this pentachlorinated furan to milk of over $40 \%$ (table 3 ). By the way, low or was transferred very differently to milk depending on medium transferred congeners were characterised studies resulting in an important SD (table 2). As for by lower MW and number of chlorination, again dioxins, hexachlorinated furans showed medium except PCB 123.

TRs to milk (11-19\%) in contrast to systematic high transfer levels to egg (23 to $40 \%)$.

\section{Transfer of PCBs}

The transfer of PCBs into milk and eggs were also presented as TRs (means and SD) and transfer levels (high, medium and low) in table 3 together with their characteristics: TEF (WHO05), Cln, log Kow and MW.

The transfer levels to eggs were classified generally as high except the di-ortho congeners 52 and 101. Except these latest, all congeners were transferred at over $30 \%$ to eggs and reached the highest TRs of 74 or $80 \%$ respectively for the PCBs 123 and 167 . The analysis of transfer to milk was built on a quite solid dataset of, depending on the congener, three to six studies (table 3 ) even if some TRs to milk were associated to high SD. This generally reflect a study effect and therefore warrants a cautious generalization (for ex. congeners 28, 52, 77,105 and 118). Except PCB 123, the most lipophilic

Nine out of 12 dioxin-like PCBs were classified as highly transferred in both food products. A special attention should be paid to the congeners presenting the highest TEFs: 126 and 169, which appeared to be highly transferred to milk and eggs with average TRs of respectively $39 \%$ and $40 \%$. Two dioxin-like, non-ortho congeners (77 and 81) showed high transfer levels in the egg study (>30\%) but much lower transfer to milk $(<13 \%)$ (table 3$)$. Only two non-dioxin-like congeners (52 and 101) presented generally low transfer levels to milk and eggs (around 5\%).

The PCA of the transfer of PCBs in milk (Figure 1A) and eggs (Figure 1B) confirmed the relationship of the transfer degree to the chemical characteristics of the congener. The first axis (F1) was mainly composed by MW, number of chlorination and lipohilicity (i.e. log Kow) explained $57.3 \%$ and $70.7 \%$ of the variation of TRs respectively to milk and eggs. The second axis (F2) was represented by the 
A-

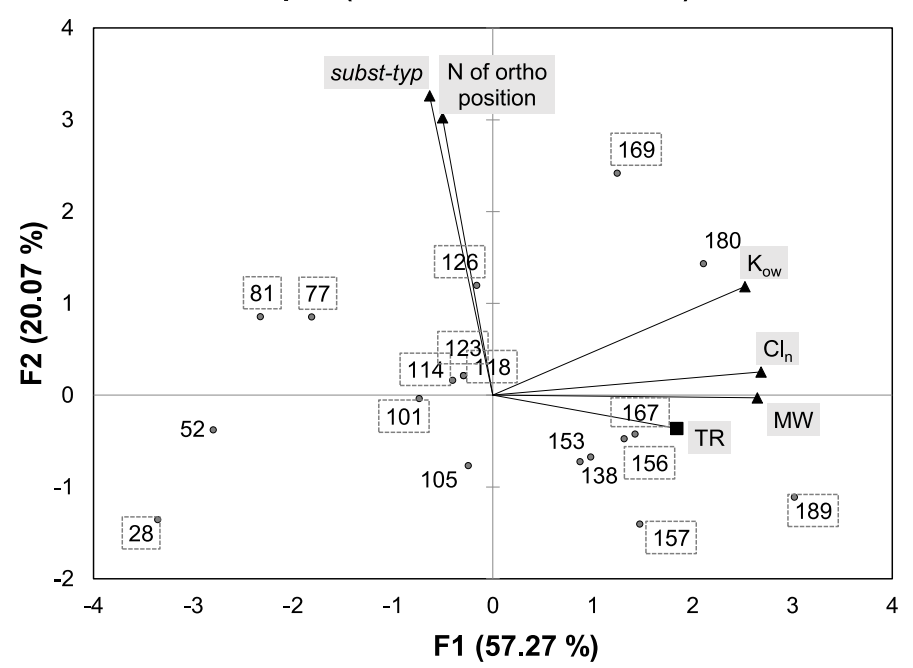

B-

Biplot (axes F1 and F2: $95.39 \%)$

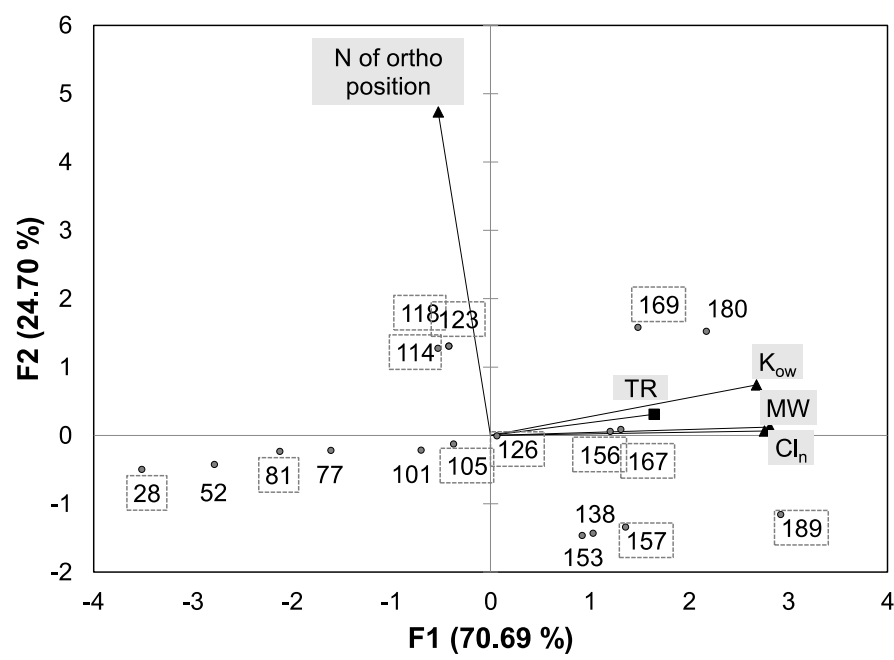

^ Active variables • Active observations — Supplementary variables

Figure 1. Factorial plan (F1, F2) of PCA applied on mean TRs of PCBs into milk (1A) and eggs (1B), position of chlorine substitution, number of chlorines (Cln), molecular weight (MW), Partition Coefficient octanol/water (Kow).

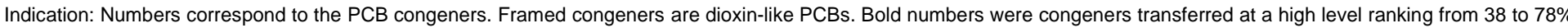
and from 30 to $80 \%$ respectively for milk and eggs.

Table 4. BCFs of PCDD/Fs of different tissues in excreting adult animals derived from literature. Colors signification: dark grey - high level of BCF (>25), medium grey - medium level of BCF (10 to 25), light grey - low level of BCF $(>1$ and $<10)$, white - no bioconcentration $(\mathrm{BCF}<1)$.

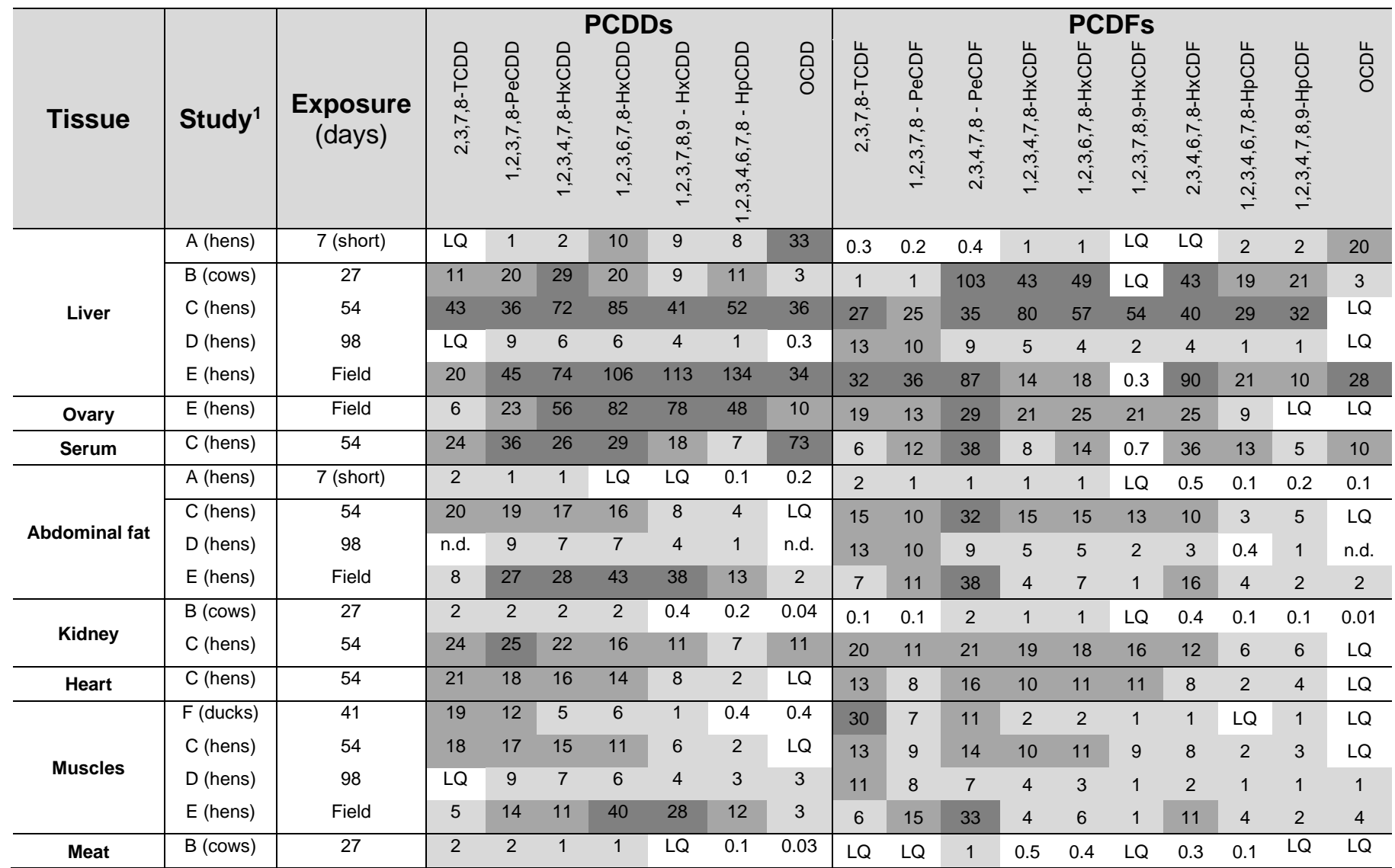

${ }^{1}$ studies: A- Traag et al., 2006, B- Huwe et al., 2005, C - Pirard and De Pauw 2005, D - Pirard and De Pauw 2006, E - Piskorska-Pliszczynska et al., 2014, F - Shih et al., 2009 $\mathrm{LQ}$ - values under the limit of quantification did not allow to calculate a BCF.

All BCFs in tissues on lipid weight basis 
substitution type and explained $20.1 \%$ and $24.7 \%$ of growing animals (table 5 ). This tendency appeared TR variations respectively for milk and eggs. especially when BCFs in liver, fat and muscles were Indeed, the first two axes of PCA explained much compared. The short time study on adults (Traag et better the variability of the transfer into eggs (95\%) than this of the transfer into milk (77\%). This analysis fitted generally well for 13 out of 18 al., 2006 in table 4) showed clearly lower BCFs contrarily to the short time study on rapidly growing animals (Hoogenboom et al., 2004 in table 5) whose congeners except PCB 28, PCB 52, PCB 77, PCB BCFs did not really stand out in comparison to the 81 and PCB 169. Pearson's correlation coefficient chronic exposure studies. In addition, the highest of MW (0.640 and 0.520), log Kow (0.618 and 0.578) BCFs of PCDD/Fs were extracted from studies with and number of chlorine atoms (0.660 and 0.586) a field exposure. As previously observed for TRs to were significantly $(P<0.05)$ correlated with TRs into excretion products, BCFs in liver and kidney of birds milk and eggs, respectively. Contrarily, the (i.e. hens) seemed higher than in (dairy) cows, even correlation between the TRs and the position of the if few data issued from very different studies incite ortho substitutions was not significant with to compare these data very carefully.

Pearson's coefficient of only 0.058 and -0.048 respectively for milk and eggs (figures $1 \mathrm{~A}$ and $1 \mathrm{~B}$ ).

\section{Transfer to tissues (BCFs)}

\section{$P C D D / F s$}

BCFs of PCDD/Fs in different tissues were presented separately for excreting adult animals (table 4, six studies) and rapidly growing animals (table 5, four studies) and indicated by the shades of grey the four bioconcentration degrees (as described previously).

Despite the difficulties to compare the data of both tables (i.e. differences between the types of animals and their metabolism), bioconcentration in adult animals (table 4) seemed higher than in rapidly

Generally, PCDDs were bioconcentrated in all studied tissues of excreting adult animals but to a very variable extent. Therefore, it seemed difficult to establish a clear hierarchy between tissues, even if BCFs in liver seemed slightly higher (except the short time study) and muscles had a slight tendency of lower BCFs (table 4). These large variations seemed to reflect a study effect. The bioconcentration of furans in the studied tissues looks similar. The comparison of the BCFs of the different congeners does not indicate clear differences. Indeed, the hierarchical order of congeners seemed to change from one study to another, and the lower TRs reported for hepta- and octachlorinated PCDD/Fs were not clearly confirmed for the BCFs.

Table 5. BCFs of PCDD/Fs of different tissues in meat producing animals derived from literature and classified in hierarchical order. Colors signification: dark grey - high level of BCF (over 25), grey - medium level of BCF (over 10 to 25), light grey - low level of BCF (overpass 1 and lower 10), white - no bioconcentration $(B C F<1)$.

\begin{tabular}{|c|c|c|c|c|c|c|c|c|c|c|c|c|c|c|c|c|c|c|c|}
\hline \multirow[b]{2}{*}{ Tissue } & \multirow[b]{2}{*}{ Study ${ }^{1}$} & \multirow[b]{2}{*}{$\begin{array}{c}\text { Exposure } \\
\text { (days) }\end{array}$} & \multicolumn{7}{|c|}{ PCDDs } & \multicolumn{10}{|c|}{ PCDFs } \\
\hline & & & 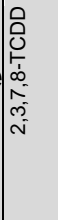 & 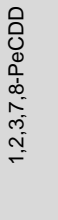 & 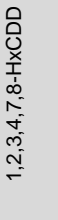 & 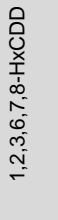 & 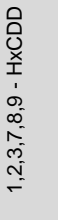 & 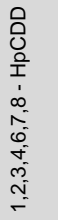 & 응 & 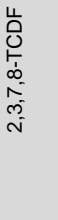 & 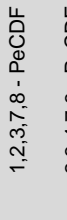 & 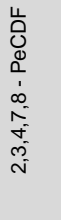 & 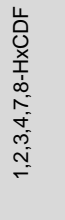 & 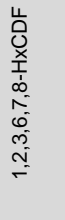 & 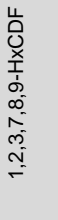 & 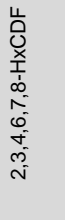 & 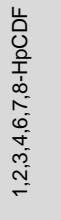 & 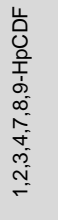 & 剀 \\
\hline \multirow{2}{*}{ Liver } & A (broilers) & 39 & 21 & 14 & 16 & 14 & 16 & 13 & 5 & 17 & 15 & 13 & 18 & 16 & 14 & 16 & 7 & 10 & 2 \\
\hline & B (lambs) & 113 & 11 & 20 & 29 & 20 & 9 & 11 & 3 & 1 & 1 & 103 & 43 & 49 & LQ & 43 & 19 & 21 & 3 \\
\hline \multirow{2}{*}{ Abdominal fat } & C (broilers) & 7 (short) & 3 & 2 & 2 & 3 & 1 & LQ & 1 & 2 & 2 & 2 & 1 & 1 & LQ & 1 & 0.3 & 0.4 & LQ \\
\hline & C (pigs) & 7 (short) & 1 & 1 & 1 & 1 & 0.3 & 1 & 1 & 0.1 & LQ & 1 & 1 & 1 & $\mathrm{LQ}$ & 0.3 & 0.4 & 0.2 & LQ \\
\hline Kidney fat & B (lambs) & 113 & 2 & 2 & 2 & 2 & 0.4 & 0.2 & 0.04 & 0.1 & 0.1 & 2 & 1 & 1 & LQ & 0.4 & 0.1 & 0.1 & 0.01 \\
\hline Muscle & B (lambs) & 113 & 2 & 2 & 1 & 1 & LQ & 0.14 & 0.03 & $\mathrm{LQ}$ & LQ & 1 & 0.5 & 0.4 & LQ & 0.3 & 0.1 & LQ & LQ \\
\hline Belly & $D$ (pigs) & 126 & 0.1 & 0.1 & 0.2 & 0.1 & 0.03 & 0.2 & 0.2 & 0.01 & 0.005 & 0.1 & 0.2 & 0.1 & n.d. & 0.1 & 0.1 & 0.1 & 0.01 \\
\hline Fore-end & D (pigs) & 126 & 0.03 & 0.02 & 0.05 & 0.03 & n.d. & 0.06 & 0.07 & n.d. & 0.03 & 0.04 & 0.04 & 0.02 & 0.03 & n.d. & 0.03 & n.d. & 0.01 \\
\hline Loin & $D$ (pigs) & 125 & 0.03 & 0.03 & 0.05 & 0.03 & 0.01 & 0.06 & 0.01 & LQ & LQ & 0.03 & 0.05 & 0.02 & n.d. & 0.02 & 0.04 & 0.02 & 0.001 \\
\hline
\end{tabular}

Studies: A - Parera et al., 2008, B - Hoogenboom et al., 2015, C - Hoogenboom et al., 2004, D- Spitaler et al., 2005

$\mathrm{LQ}$ - values under the limit of quantification did not allow to calculate a BCF.

All BCFs in tissues on lipid weight basis 
In rapidly growing animals (table 5) notable BCFs were reported only in liver and did hardly exceed 1 in the other tissues (different fats and muscles). Unfortunately, several tissues were confounded with an effect of studies and even of species but bioconcentration in fat (abdominal and kidney) seemed to vary around 1 and dropped under 1 (i.e. no clear bioconcentration) in different muscles (table 5). In these animals, BCFs of hepta- and octachlorinated congeners were lower than in less chlorinated ones, especially hexachlorinated PCDD/Fs (table 5).

\section{Polychlorinated biphenyls}

Dataset for the bioconcentration of PCBs in different tissues were derived from six studies which differed widely by the type of exposed animals and by the exposure durations (table 6). Therefore, comparisons and generalizations were complicated despite the interesting size of the dataset.

Mainly low BCFs (i.e. <10) have been shown in short time studies (Hoogenboom et al.,2004; Traag et al.,2006) or studies on excreting adult animals (Pirard and De Pauw, 2005; Huwe et al., 2005;

Table 6. BCFs of PCBs of different tissues in food producing animals derived from literature and classified in hierarchical order. Colors signification: dark grey - high level of BCF (over 25), grey - medium level of BCF (over 10 to 25), light grey - low level of BCF (overpass 1 and lower 10), white - no bioconcentration (BCF $<1$ ).

\begin{tabular}{|c|c|c|c|c|c|c|c|c|c|c|c|c|c|c|c|c|c|c|c|c|}
\hline \multirow{2}{*}{ Tissue } & \multirow{2}{*}{ Study $^{1}$} & \multirow{2}{*}{$\begin{array}{c}\text { Exposure } \\
\text { (days) }\end{array}$} & \multicolumn{18}{|c|}{ PCB congener } \\
\hline & & & 28 & 52 & 77 & 81 & 101 & 105 & 114 & 118 & 123 & 126 & 138 & 153 & 156 & 157 & 167 & 169 & 180 & 189 \\
\hline \multirow{5}{*}{ Liver } & A (hens) & 7 (short) & & 0 & 0.2 & 0.2 & 0 & 0 & 0 & 0 & & 0.4 & 0 & 0 & 0 & 0 & 0 & 1 & 0 & 0 \\
\hline & $\begin{array}{l}\text { B (dairy } \\
\text { cows) }\end{array}$ & $17-38$ & & & & & \multirow[b]{4}{*}{0.4} & & \multirow[b]{4}{*}{ LQ } & & & 21 & & & & & & 5 & & \multirow[b]{4}{*}{ LQ } \\
\hline & C (hens) & 54 & & & 2 & 3 & & & & & & 8 & & & & & & 7 & & \\
\hline & D (goats) & 80 & & & 1 & & & 3 & & 3 & 3 & 23 & 10 & & 4 & 5 & 5 & & & \\
\hline & $\begin{array}{l}\mathrm{E} \\
\text { (lambs) }\end{array}$ & 113 & 1 & $\mathrm{LQ}$ & 0.1 & 5 & & 6 & & 4 & LQ & 46 & 27 & 62 & 9 & 15 & 4 & 26 & 25 & \\
\hline Serum & C (hens) & 54 & & & 2 & 8 & & & & & & 15 & & & & & & 16 & & \\
\hline \multirow{6}{*}{$\begin{array}{l}\text { Abdominal } \\
\text { fat }\end{array}$} & $\begin{array}{l}\text { A (hens) } \\
F\end{array}$ & $\begin{array}{l}7 \text { (short) } \\
7 \text { (short) }\end{array}$ & 0.5 & 0.2 & 2 & 2 & 0.4 & 1 & 1 & 1 & & 2 & 2 & 2 & 1 & 1 & 1 & 1 & 2 & 1 \\
\hline & (broilers) & & 1 & 1 & 2 & 3 & \multirow{2}{*}{$\begin{array}{l}1 \\
1 \\
\end{array}$} & \multirow{2}{*}{$\begin{array}{l}3 \\
1 \\
\end{array}$} & \multirow{2}{*}{$\begin{array}{l}2 \\
1 \\
\end{array}$} & \multirow{2}{*}{$\begin{array}{l}2 \\
1 \\
\end{array}$} & \multirow{2}{*}{\multicolumn{2}{|c|}{$\begin{array}{l}4 \\
1 \\
\end{array}$}} & \multirow{2}{*}{$\begin{array}{l}2 \\
1 \\
\end{array}$} & \multirow{2}{*}{$\begin{array}{l}2 \\
1 \\
\end{array}$} & \multirow{2}{*}{$\begin{array}{l}2 \\
1 \\
\end{array}$} & \multirow{2}{*}{$\begin{array}{l}3 \\
1 \\
\end{array}$} & \multirow{2}{*}{$\begin{array}{l}3 \\
1 \\
\end{array}$} & \multirow{2}{*}{$\begin{array}{l}3 \\
1 \\
\end{array}$} & \multirow{2}{*}{$\begin{array}{l}2 \\
1\end{array}$} & \multirow{2}{*}{$\begin{array}{l}2 \\
1 \\
\end{array}$} \\
\hline & F (pigs) & 7 (short) & 0.2 & 1 & 0.1 & & & & & & & & & & & & & & & \\
\hline & C (hens) & 54 & & & 1 & 4 & & & & & & 11 & & & & & & 10 & & \\
\hline & D (goats) & 80 & & & 0.4 & & & 3 & & 6 & 1 & 4 & 4 & & 6 & 6 & 7 & & & \\
\hline & $\begin{array}{l}\mathrm{E} \\
\text { (lambs) }\end{array}$ & 113 & 1 & LQ & 0.1 & 1 & 0.3 & 5 & LQ & 4 & LQ & 2 & 3 & 16 & 14 & 18 & 4 & 13 & 14 & $\mathrm{LQ}$ \\
\hline \multirow{2}{*}{ Muscle } & \multirow{2}{*}{$\begin{array}{l}\mathrm{C} \text { (hens) } \\
\mathrm{E} \\
\text { (lambs) }\end{array}$} & \multirow{2}{*}{$\begin{array}{r}54 \\
113\end{array}$} & & & 6 & 10 & \multirow[b]{2}{*}{ LQ } & & \multirow[b]{2}{*}{ LQ } & & \multirow[b]{2}{*}{ LQ } & 10 & & & & & & 11 & & \multirow[b]{2}{*}{ LQ } \\
\hline & & & 1 & LQ & 0.2 & 1 & & 3 & & 3 & & 2 & 2 & 8 & 8 & 11 & 3 & 8 & 7 & \\
\hline Heart & C (hens) & 54 & & & 2 & 4 & & & & & & 6 & & & & & & 7 & & \\
\hline Kidney & C (hens) & 54 & & & 3 & 4 & 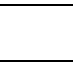 & 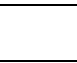 & 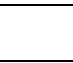 & & 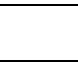 & 8 & $\square$ & & 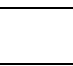 & & & 8 & & \\
\hline
\end{tabular}

Ounnas et al., 2010). Only chronic exposure study group of congeners $(77,81,105,118$ and probably on growing sheep (Hoogenboom et al., 2015b) 123). Finally, no or only low bioconcentrations reported medium or high BCFs in liver and in (BCFs $\leq 1)$ were revealed for PCBs 28, 52, 101, 114, abdominal fat (table 6).

The hierarchy between PCB congeners within a same tissue of a given study seemed clearer: The strongest bioconcentration was shown for congener 126, but also for some higher congeners (i.e. more chlorinated and more lipophilic) 138, 153, 156, 157, 169 and 180. Low but significant bioconcentration (i.e. BCFs up to 10) was revealed for a second and 189. The chronic exposure study on growing lambs (Hoogenboom et al., 2015b) reported another interesting result: no $(<L O Q)$ or very low bioconcentration were observed for PCBs 28, 52, $77,81,101,114$, and 123 in liver and fat, whereas medium to high BCFs were found for congeners 126 and 138 only in liver, but for PCBs 153, 156, $157,167,169$ and 180 in both tissues 
Table 7. Comparison of bromination $\left(\mathrm{Br}_{\mathrm{n}}\right)$, molecular weight $(\mathrm{MW})$, Log of partition coefficient octanol-water (Log $\mathrm{K}_{\mathrm{ow}}$ ) and bioconcentration factors of PBDEs of different tissues in cows $(\mathrm{A})$ and goats $(\mathrm{B})$. Colors signification: dark grey - high level of BCF (over 25), grey - medium level of BCF (over 10 to 25), light grey - low level of BCF (overpass 1 and lower 10), white - no bioconcentration $(B C F<1)$.

\begin{tabular}{|c|c|c|c|c|c|c|c|c|c|}
\hline \multirow{3}{*}{ Study ${ }^{1}$} & \multirow{2}{*}{\multicolumn{3}{|c|}{ Chemical characteristics }} & \multicolumn{6}{|c|}{ Tissues } \\
\hline & & & & \multicolumn{2}{|c|}{ Liver } & \multirow{2}{*}{$\begin{array}{c}\text { Heart } \\
\text { A }\end{array}$} & \multicolumn{2}{|c|}{ Fat } & \multirow{2}{*}{$\begin{array}{c}\text { Kidney } \\
\text { A }\end{array}$} \\
\hline & MW & $\mathrm{Br}_{\mathrm{n}}$ & $\log k_{o w}{ }^{2}$ & A & B & & A & $B$ & \\
\hline BDE 28 & 407 & 3 & 5.9 & 1 & & 1 & 1 & & 0.4 \\
\hline BDE 47 & 486 & 4 & 6.8 & 9 & 5 & 6 & 5 & 2 & 2 \\
\hline BDE 49 & 486 & 4 & 6.3 & LQ & & LQ & 0.4 & & LQ \\
\hline BDE 66 & 486 & 4 & 6.3 & LQ & & LQ & 1 & & LQ \\
\hline BDE 85 & 565 & 5 & 7.4 & LQ & & LQ & 2 & & LQ \\
\hline BDE 99 & 565 & 5 & 7.3 & 4 & 3 & 4 & 4 & 2 & LQ \\
\hline BDE 100 & 565 & 5 & 7.2 & LQ & & LQ & 6 & & LQ \\
\hline BDE 153 & 644 & 6 & 7.9 & 5 & & 6 & 10 & & 3 \\
\hline BDE 154 & 644 & 6 & 7.8 & 9 & & 6 & 7 & & 5 \\
\hline
\end{tabular}

1 A - Kierkegaard et al. 2009, B - Ounnas et al. 2010

${ }^{2}$ Log kow derived from Braekevelt et al. 2003 except for BDEs 49 and 66 which were derived from Kierkegaard et al. 2007.

$\mathrm{LQ}$ - values under the limit of quantification did not allow to calculate a BCF.

${ }^{3}$ All BCFs in tissues on lipid weight basis

\section{Polybrominated diphenyl ethers (PBDEs)}

Bioconcentration factors of PBDEs were derived from studies on lactating cows (Kierkegaard et al., 2009) or lactating goats (Ounnas et al., 2010) and presented in the table 7. Generally, bioconcentration seemed limited and never exceed 10. Moreover, several congeners (BDE 28, 49, 66 and 85 ) were not bioconcentrated and only BDEs 47,153 and 154 reached a notable but low level of BCFs of 6 to 7 (table 7). As previously noted for PCBs, the BCFs of PBDEs also increased with the lipophilicity (i.e. log kow) of the congeners.

\section{Organochlorinated pesticides}

Bioconcentrations of dichlorodiphenyltrichloroethane (DDT) and its metabolites as well as hexachlorocyclohexane $(\mathrm{HCH})$ isomers in edible chicken tissues (Aulakh et al., 2006; Tao et al., 2009) and in yak tissues (Pan et al., 2014) were presented in table 8 .

BCFs of DDT ranked up to 50 . Indeed, one of the most persistent organochlorine pesticide $p, p^{\prime}$-DDT demonstrated high BCFs in all studied chicken tissues: stomach (50), skin (36), liver (18) and muscle (17). However, even the DDT metabolites DDD and DDE presented low to medium levels of bioconcentration (table 8). Values from the -study on lactating yaks were very low $(<1)$. It is not clear if this study effect can be attributed to this specie or the experimental conditions.

Table 8. Bioconcentration factors of DDT and $\mathrm{HCH}$ isomers in different tissues of chicken (study 1: Tao et al. 2009; study 2:Auklakh et al. 2006) or yak (Pan et al 2014). Colors signification: dark grey - high level of BCF (over 25), grey - medium level of BCF (over 10 to 25), light grey - low level of BCF (overpass 1 and lower 10), white - no bioconcentration $(\mathrm{BCF}<1)$.

\begin{tabular}{|c|c|c|c|c|c|c|c|c|}
\hline \multirow[t]{2}{*}{ Compound } & \multirow{2}{*}{$\begin{array}{c}\text { stomach } \\
\text { (gizzard) } \\
\text { Chicken }{ }^{1}\end{array}$} & \multicolumn{2}{|c|}{ liver } & skin & \multicolumn{3}{|c|}{ muscle } & \multirow{2}{*}{$\begin{array}{c}\text { eggs } \\
\text { TR } \\
\text { Chicken }^{2}\end{array}$} \\
\hline & & Chicken ${ }^{1}$ & yak & Chicken ${ }^{1}$ & Chicken ${ }^{1}$ & Chicken $^{2}$ & yak & \\
\hline \multicolumn{9}{|c|}{ DDT and its metabolites } \\
\hline $\mathrm{p}, \mathrm{p}^{\prime}-\mathrm{DDT}$ & 50 & 18 & 0.3 & 36 & 17 & 1 & 0.5 & 14 \\
\hline o,p'-DDT & 10 & 24 & na & 6 & 6 & nd & na & 15 \\
\hline$p, p^{\prime}-D D E$ & 14 & 5 & 0.5 & 4 & 6 & 7 & 0.4 & 58 \\
\hline o,p'-DDE & 5 & 20 & na & 6 & 5 & 3 & na & 35 \\
\hline$p, p^{\prime}-D D D$ & 14 & 9 & nd & 5 & 4 & 2 & nd & 54 \\
\hline o,p'-DDD & 10 & 11 & na & 13 & 5 & 2 & na & 19 \\
\hline \multicolumn{9}{|l|}{$\mathrm{HCH}$ isomers } \\
\hline$\alpha-\mathrm{HCH}$ & 5 & 21 & 0.3 & 5 & 2 & 0.3 & 0.3 & 6 \\
\hline$\beta-\mathrm{HCH}$ & 21 & 34 & 28 & 12 & 12 & 3 & 2 & 32 \\
\hline $\mathrm{Y}-\mathrm{HCH}$ & 3 & 2 & 0.5 & 3 & 2 & 1 & 0.9 & 22 \\
\hline$\delta-\mathrm{HCH}$ & 2 & 8 & na & 1 & 1 & nd & na & \\
\hline
\end{tabular}


Similar results were obtained for $\mathrm{HCHs}$ which bioconcentration ranked from low to high depending on the congener and the considered tissue. Bioconcentration was highest for $\beta-\mathrm{HCH}$ (between 3 and 34). In contrast, accumulation of $\gamma-\mathrm{HCH}$ (i.e. lindane) seemed limited with BCFs, which did not overpass 3 in all studied tissues. Except $\gamma-\mathrm{HCH}$, BCFs in liver were clearly higher than in the gizzard, in which the three other isomers were more bioconcentrated than in skin and muscle. Contrarily, bioconcentration of $\gamma-\mathrm{HCH}$ varied few between the studied tissues (table 8).

Recalculated TRs of DDT to eggs seemed to indicate high transfer of both OCPs as previously stated for PCDD/Fs and PCBs.

\section{Discussion}

\section{Methodological considerations of the concepts of TR and BCF}

TRs and BCFs are both valuable concepts to describe contaminant transfer into food products. Nevertheless, their meaningfulness is conditioned by several parameters. The main limit in transfer studies of POPs in vivo consists in the completion of steady state. Firstly, this commonly accepted condition (see also Material and Methods) was difficult to calculate accurately as the preciseness of modelized curves depends on the number and spacing of the experimental points. Besides the aspect of costs of numerous analysis, any approximation in the measurement of very low concentrations of POPs in the studied tissue would considerably increase the confidence interval around the asymptote of the logarithmic enrichment curve. Therefore, numerous authors calculated the necessary time of exposure via the half-life of the target compound but experiments were generally based on a group of congeners whereas the halflive can vary considerably between the different congeners of the same family. Indeed, half-lives have been estimated for PCDD/Fs at several weeks (7 weeks) in laying hens (Traag et al., 2004) and cows (50 days) (Firestone et al., 1979). Olling et al. (1991) estimated half-life for PCDD/Fs ranging from $40 \pm 7.7$ days for $2,3,7,8-T C D D$ to $34 \pm 13$ days for $1,2,3,4,6,7,8-H p C D$. PCBs presented also different half-lives according to their chlorination: half-life of PCB 101 in lactacting goats were reported at $<4$ days whereas PCB 180 showed half-life greater than 8 days (Fournier et al., 2013). Sum of PBDEs presented half-lives of 58 days in dairy cows (Fries and Marrow, 1975). Half-life of DDT in egg yolk was estimated to be of 7.6 days (Furusawa and Morita, 2001). Finally, the half-life time should be compatible with the life expectancy of the studied animal: easy to respect for animals such as laying hens (around 1 year), goats and cows (approximately 5 years), but very complicated in chicken which are generally farmed only 2 months for producing meat. Thus, the determination of the minimal exposure time will be always a subjective compromise but should target to approach as good as possible the steady state conditions in the studied animal. This motivated our initial condition to require an exposure time of around 50 days when PCDD/Fs were studied in long life cattle but accepted quite shorter exposure times for PCBs. The achievement of steady state seems impossible when tissue enrichment was studied, i.e. BCF approaches. In rapidly growing animals, the tissue enrichment by the compound intake would be permanently diluted by the body mass gain. In adults with more or less stable body weight, excretions like milk or eggs would at least slow down the achievement of steady state. Therefore, the comparison of bioconcentration between different studies, using different animals with different metabolic status, seems too difficult. Bioconcentration hierarchy can be drawn out between congeners or tissues within the same study (same exposure dose and duration, same animals) and then, these hierarchic orders between congeners or tissues can be compared. Another aspect, especially for BCFs, consisted in the comparison to the concentration in the intake matrix, generally feed. Nevertheless, it is possible that other ingested matrices as soil, water or contaminated vegetable cover would also be contaminated and leading to an underestimation of the real exposure concentration. Finally, the statistical power depends on the number of available data. Indeed, the analysis of the PCDD/Fs transfer to milk built on 8 studies seems quite solid contrarily to the OCP transfer where the small number of data makes it rather a first exploratory approach.

Accepting these minimal requirements, the concepts of TRs and BCFs are very useful to hierarchize the extent of transfer between different tissues or also between different compounds. Such a ranking is very useful to give recommendations in risk assessments. Indeed, full interdiction of any food produced in contaminated areas makes local people completely dependent from importations while targeting only the most hazardous tissues of the contaminated animals would allow reducing 
significantly the consumer's exposure maintaining local food supply.

\section{Transfer mechanisms}

Transfer of POPs to organs and excreted product results from a succession of physiological steps: Absorption, Metabolization, Distribution and Excretion.

Absorption is driven by (i) the physiological characteristics i.e. the animal species and (ii) the chemicals properties of the molecule. Absorption of POPs is the first key process determining the transfer of persistent compounds to livestock. Studied compounds were mainly absorbed in the intestine by crossing the epithelium wall, most of the studied compounds by a transcellular route (entering the intestinal epithelial cell by crossing the plasma membrane) (Kelly et al., 2004; Sanford, 1992). From a mechanistically point of view, lipophilic compounds are mostly transported in micelles formed by excreted bile salts and lipids present in the chyme (Kelly et al., 2004). These micelles containing lipophilic POPs, crossed an aqueous thin layer covering the intestinal wall, conceptualized and referred as the Unstirred Water Layer, before crossing intestinal epithelium cells (Kelly et al., 2004) and subsequently reaching blood or lymph streams. As these mechanisms involved aqueous phase and amphiphilic micelles, lipophilicity appears as a key characteristic explaining this absorption efficiency (McLachlan, 1993; Drouillard and Nordstrom, 2003; Kelly et al., 2004). For different species like dairy cows (McLachlan, 1993) and birds (Drouillard and Nordstrom, 2003), this efficiency is higher for medium lipophilic molecules and decrease after a threshold value of the partition coefficient Kow. This threshold and the extent of the reduction appears to be species-dependent (Kelly et al., 2004). In birds, models illustrate a very high absorption efficiency (close to $100 \%$ ) of ingested dose until a log of Kow of 8.0, then a slow reduction of efficiency appears for higher Kow mainly explained by the ultimate Unstirred Water Layer. Indeed, this aqueous layer constitutes a physical limitation to solubilization of the most lipophilic compounds. Concerning dairy cow, and due to its particular polygastric digestive system, absorption efficiency of lipids is lower (80\%) and the efficiency threshold is attained for lower Kow (7.0) (McLachlan, 1993). Then a drastic reduction of absorption efficiency occurs for more lipophilic compounds: absorption efficiency is lower than $35 \%$ for molecules displaying Kow of 8.0
(McLachlan, 1993). These elements are in line with the present results for highly chlorinated dioxins: TRs and BCFs displaying lower values than less lipophilic compounds of the same chemical family. In addition, a greater transfer reduction was obtained in milk compared to eggs, highlighting the potential difference of absorption between species for the highest lipophilic compound, especially for PCDD/Fs.

Metabolization of molecules can take place in distinct phases: in the intestinal lumen, in the liver, in the endothelial cells of blood vessels and in the deposition organs. The hepatic metabolism was the most investigated path of biotransformation of the studied compounds. The BCFs in liver were globally higher than in other organs which may result from a high first pass effect (i.e. xenobiotic metabolism occurring after absorption and before the reach of systemic circulation) for these molecules or a specific sites of binding notably enzyme binding (Ohtake et al., 2007). If few data were obtained for reared animals such as dairy cows, laying hens or chickens, some studies highlighted the specific role of monooxygenase enzymes cytochrome (like CYP1A2 and CYP1A1) and AhR (aryl hydrocarbon receptor) which could explain these high concentrations in the liver (Kuroki et al, 1986, Casarett and Doull, 2008). It should also be noticed that the metabolization rate was found or suspected low for the majority of studied compounds: as shown for PCDD/Fs (Adolphs et al., 2013), PBDEs (Kohli et al., 1978), PCBs (Lutz et al., 1977; Matthews and Dedrick, 1984), DDTs (Casarett and Doull, 2008). Congeners within each POP family present distinct metabolization rates as proven for PCBs for which substitution appeared as a main factor of variation (McLachlan, 1993). However, HCH metabolization appears extensive (ATSDR, 2005) which seems in line with the reduced levels of BCFs found in chicken muscles compared to hepatic tissues. If few data are available concerning PBDE metabolization, debromination of PBDEs was suspected in dairy cows (Kierkegaard et al., 2007) as it was shown elsewhere in fish (Stapelton et al., 2004) and rats (Morck et al., 2003), without a proper demonstration of its existence, extent nor specific mechanism.

The distribution of POPs to organs is realized through blood. Different blood constituents such as lipoproteins (HDL, VLDL, IDL, LDL) and albumins are known to vehicles POPs (Casarett and Doull, 2008, Soine et al., 1982, Delannoy et al., in press). Distribution of these lipophilic POPs result in preferential accumulation of lipophilic POPs in lipid- 
rich organs. Found results illustrated this fact for the most lipophilic congeners (i.e. log Kow >7.2) as levels present in muscle tissue, kidneys or heart are generally lower than in adipose tissue, and ovary follicles. Concerning milk and eggs, it is already known that lactating and laying involve a remobilization of POPs from adipose tissue stock to milk and eggs (Gobas et al., 2003; Kierkegaard et al., 2007; Fournier et al., 2011).

\section{Excretion of PCDD/Fs, PCBs, PBDEs, $\mathrm{HCH}$ and} DDT isomers may be realized through several routes: fecal egestion, bile and urinary excretion represent secondary routes whereas milk and egg excretion constitute the major ones. The importance of excreted food product in the excretion of lipophilic compounds is related to the co-excretion of fat along egg or milk. This explains that most of Quantitative Structure Activity Relationships model to predict milk and egg excretion implements log of Kow (Gobas et al., 2003). These elements are in line with these data and could illustrate the differences found in terms of BCFs: highest BCF were found for $\mathrm{PCDD} / \mathrm{Fs}$, DDT and $\mathrm{HCH}$ (highest Kow), then PCB (medium Kow) and the lowest for PBDEs (low Kow).

\section{Toxicity and implications in food safety}

Lipophilic POPs are not only highly transferred to edible products such as milk, eggs, meat and offal, but even more, these food products present higher POPs exposure sources than the animal feed carrying them. In this context, PCDD/Fs appeared as the most problematic compound family regarding, notably, their reprotoxicity and carcinogenic potential along their high potency to transfer in animal food products. Indeed, BCFs higher than 10 and TRs over 33\% were found for all congeners except the highest chlorinated ones, also known to be less toxic. $\mathrm{HCH}$ isomers present, notably, neurotoxicity, reprotoxicity and hepatotoxicity. Similarly, the most toxic congeners $(\gamma-\mathrm{HCH}$ and $\beta-\mathrm{HCH}$ ) appeared also to be the most transferred to food of animal origin (Table 8, ATSDR, 2005). Concerning DDT and its ortho and para metabolites DDE and DDD similar patterns of toxicity were reported by ATSDR (2020), notably neurodevelopmental toxicity, reprotoxicity and hepatotoxicity. BCFs over 10 illustrated their potency to bioconcentrate. Finally, neurotoxicity, reprotoxicity and endocrine disruption were also reported for PBDEs (ATSDR, 2017), with higher toxicity for less brominated compounds. BDE 47 appears to be the most problematic congener in terms of food safety as it is one of the most transferred to food product and presents high toxicity. Health effects associated to PCB exposure in humans and/or animals include hepatic, thyroid, dermal and ocular changes, immunological and neurodevelopmental alterations, reduced birth weight, reproductive toxicity, and cancer (ATSDR, 2000). They present also the highest TRs emphasizing their high potency to be transferred into milk and eggs.

\section{Conclusion}

The understanding of POP transfer into food of animal origin is a huge field of investigation necessary to ensure food safety and therefore the sustainability of livestock productions. Through the present meta-analysis of many but very different experimental or case studies, a better understanding of the transfer of POPs was attempted. Thus, TRs and BCFs are shown to be valuable tools to describe and assess contaminant's transfer to animals and their subsequent foodproducts. They allow to predict maximum POP levels when the exposure context (ingest dose of POPs) is accurately known, and play by consequence a major role in risk assessments dealing with food contaminations. However, to derive them, a careful attention must be paid to the duration of animals exposure in order to reach conditions as close as possible to steady state. For lipophilic elements such as POPs the duration could be challenging and numerous valuable articles could not reach this appropriate length. Nevertheless, selected literature provides helpful insight concerning POPs behavior and to expected levels in edible products. Lipophilicity tend to these POPs to be excreted or accumulated in fatty tissues. Unfortunately, the most toxic POPs (tetra- to hexachlorinated dioxins and furans, highly chlorinated PCBs, especially congener 126, as well as DDT) are highly transferred to the most consumed food products such as eggs, milk, and to a lesser extent also meat. The bioconcentration of these pollutants could threaten the animal rearing system. This risk must be considered in free-range rearing systems and especially when the surrounding environment of the system is contaminated.

\section{References}

Abrahams P.W., Steigmajer J. 2003. Soil Ingestion by Sheep Grazing the Metal Enriched Floodplain Soils of Mid-Wales. Environ. Geochemistry Health 25, 17-24.

Adolphs, J., Kleinjung, F., Numata, J., Mielke, H., Abraham, K., Schafft, H., Muller-Graf C., Greiner, M. 2013. A probabilistic model for the carry-over of PCDD/Fs from feed to growing pigs. Chemosphere 93, 474-479.

ATSDR, 2000. Toxicological profile for polychlorinated biphenyls (PCBs). Atlanta: Agency for Toxic Substances and Disease Registry, November 2000 https://www.atsdr.cdc.gov/ToxProfiles/tp17.pdf. 
ATSDR, 2005 « Toxicological profile for Hexachlorocyclohexane. Atlanta: Agency for Toxic Substances and Disease
https://www.atsdr.cdc.gov/ToxProfiles/tp43.pdf.

ATSDR, 2017. Toxicological profile for Polybrominated Diphenyl Ethers (PBDEs) " Atlanta: Agency for Toxic Substances and Disease Registry, March 2017. https://www.atsdr.cdc.gov/toxprofiles/tp207.pdf.

ATSDR, 2020. Toxicological profile for DDT, DDE, and DDD. Atlanta: Agency for Toxic Substances and Disease Registry, March 2020. https://www.atsdr.cdc.gov/ToxProfiles/tp35.pdf

Aulakh, R.S., Bedi, J.S., Sharma, J.K., Joia, B.S., Ockerman, H.W. 2006. Organochlorine pesticide residues in poultry feed, chicken muscle and eggs at a poultry farm in Punjab, India. J. Sci. Food Agric. 86, 741-744.

Bley T.A.G., Bessei W. 2008. Recording of individual feed intake and feeding behavior of Pekin ducks kept in groups. Poultry Sci. 87, 215-221.

Brambilla, G., Fochi, I., Falce, M., De Filippis, S.P., Ubaldi, A., Di Domenico, A. 2008. PCDD and PCDF depletion in milk from dairy cows according to the herd metabolic scenario. Chemosphere 73, 216-219.

Bryan, A. 2012. PCDD/F and PCB levels in beef from cattle raised on flood plainsS. Organohalogen Compounds 74, 5 .

Casarett, L.J., Doull, J. 2008. Casarett and Doull's Toxicology: The Basic Science of Poisons. $6^{\text {th }}$ éd. Curtis D. Klaassen, McGraw-Hill Medical Pub. Division.

Chen, J., Quan, X., Yazhi, Z., Yun, Y., Yang, F., 2001. Quantitative structure-property relationship studies on n-octanol/water partitioning coefficients of PCDD/Fs.Chemosphere44 (6), 1369-1374. doi:10.1016/S0045-6535(00)00347-7.

Collas C., Mahieu M., Tricheur A., Crini N., Badot P.M., Archimède H., Rychen G., Feidt C., Jurjanz S. 2019. Cattle exposure to chlordecone through soil intakes. The casestudy of tropical grazing practices in the French West Indies. Sci. Tot. Environ. 668, 161-170

Costera, A., Feidt, C., Marchand, P., Le Bizec, B., Rychen, G. 2006. PCDD/F and PCB transfer to milk in goats exposed to a longterm intake of contaminated hay. Chemosphere 64, 650-657.

Delannoy, M., Girardet, J.-M., Djelti, F., Yen Potin, F., Cakir-Kiefer, C. 2020. Affinity of chlordecone and chlordecol for human serum lipoproteins. Environ. Toxic. Pharmac. in press. https://doi.org/10.1016/j.etap.2020.103486

Diletti, G., Ceci, R., Ippoliti, C., Ferri, N., Marchi, E., Pirito, L., Scortichini, L. 2014. PCDD/F and DL-PCB transfer to milk in buffaloes exposed to contaminated feed. Organohalogen. Comp. 76, 1557-1560.

Drouillard, K.G., Norstrom R.J. 2003. The influence of diet properties and feeding rates on PCB toxicokinetics in the ring dove. Arch. Environ. Contam. Toxic. 44, 97-106.

Feil, V.J., Huwe, J., Zaylskie, R.G., Davison, K.L. 2000. Chlorinated Dibenzo-p-dioxin and Dibenzofuran Concentrations inBeef Animals from a Feeding Study. J. Agric. Food Chem. 48,6163-6173.

Fernandes, A.; Foxall, C.; Lovett, A.; Rose, M.; Dowding, A. 2011. The assimilation of dioxins and $\mathrm{PCB}$ in conventionally reared farm animals: occurrence and biotransfer factors. Chemosphere 83, 815-822, doi:10.1016/j.chemosphere 2011.02.083.

Firestone, D., Clower Jr, M., Borsetti, A.P., Teske, R.H., Long, P.E. 1979. Polychlorodibenzo-p-dioxin and pentachlorophenol residues in milk and blood of cows fed technical pentachlorophenol. J. Agric. Food Chem. 27, 1171-1177.

Fournier, A., Feidt, C., Marchand, Ph., Venisseau, A., Le Bizec, B., Seiller, N., Engel, E. Ratel, J., Travel, A., Jondreville, C. 2011. Kinetic study of $\square$ hexabromocyclododecane orally given to laying hens (Gallus domesticus). Environ. Sci. Poll. Res. 19, 440-447.

Fournier, A., Rychen, G., Marchand, P., Toussaint, H., Le Bizec, B., Feidt, C. 2013. Polychlorinated biphenyl (PCB) decontamination kinetics in lactating goats (Capra hircus) following a contaminated corn silage exposure. J. Agric. Food Chem. 61, 71567164

Fries, G.F., Marrow, G.S. 1975. Excretion of polybrominated biphenyls into the milk of cows. J. Dairy Sci. 58, 947-951.

Fries G.F., Marrow G.S., Snow P.A. 1982. Soil Ingestion by Dairy Cattle. J. Dairy Sci. 65 , 611-618

Fries, G.F., Paustenbach, D.J., Mather, D.B., Luksenburg, W.J. 1999. A congener specific evaluation of the transfer of polychlorinated dibenzo-p-dioxins and dibenzofurans to milk of cows following ingestion of pentachlorophenol treated wood. Environ. Sci. Technol. 33, 1165-1170.

Fries, G.F., Paustenbach, D.J., Luksenburg, W.J. 2002. Complete mass balance of dietary polychlorinated dibenzo-p-dioxins and dibenzofurans in dairy cattle and characterization of the apparent synthesis of hepta- and octachlorodioxins. J. Agric. Food Chem 50, 4226-4231.

Furusawa, N., Morita, Y. 2001. Residual profile of DDT in egg yolks of laying hens following an oral application. NZ J. Agric. Res. 44, 297-300.

Gobas F.A.P.C., Kelly, B.C., Arnot, J.A. 2003. Quantitative structure activity relationships for predicting the bioaccumulation of POPs in terrestrial food webs. QSAR \& Combinatorial Science 22, 329-336.

Govers, H., Krop, H., 1998. Partition constants of chlorinated dibenzofurans and dibenzop-dioxins. Chemosphere37 (9-12), 2139-2152. doi:10.1016/S0045-6535(98)00276-8 Healy W.B. 1968. Ingestion of soil by dairy cows. NZ. J. Agric. Res. 11, 487-499.

Holford, N.H.G. 2012. Pharmacokinetics \& pharmacodynamics: rational dosing \& the time course of drug action, 11th ed, Basic \& clinical pharmacology. McGraw-Hill Medical, New York.

Hoogenboom, L.A., Kan, C.A., Bovee, T.F., van der Weg, G., Onsteng, C., Traag, W.A. 2004. Residues of dioxins and PCBs in fat of growing pigs and broilers fed contaminated feed. Chemosphere 57, 35-42.

Hoogenboom, L.A., Kan, C.A., Zeilmaker, M.J., van Eijkeren, J., Traag, W.A. 2006. Carryover of dioxins and PCBs from feed and soil to eggs at low contamination levels influence of mycotoxin binders on the carry-over from feed to eggs. Food Addit. Contam. 23, S18-S27.

Hoogenboom, L.A., Klop, A., Herbes, R., van Eijkeren, J.C.H., Zeilmaker, M.J., van Vuuren, A.M., Traag, W.A., 2015 a. Carry-over of polychlorinated dibenzo-p-dioxins and dibenzofurans (PCDD/Fs) and polychlorinated biphenyls (PCBs) in dairy cows fed smoke contaminated maize silage or sugar beet pulp. Chemosphere 137, 214-220.

Hoogenboom, R.L.A.P.; Stark, M.L.; Spolders, M.; Zeilmaker, M.J.; Traag, W.A.; ten Dam, G.; Schafft, H.A. 2015 (b). Accumulation of polychlorinated dibenzo-p-dioxins, dibenzofurans, and biphenyls in livers of young sheep. Chemosphere, 122, 137-144, doi:10.1016/j.chemosphere.2014.11.030.
Huwe, J.K., Smith, D.J. 2005. Laboratory and on-farm studies on the bioaccumulation and elimination of dioxins from a contaminated mineral supplement fed to dairy cows. J. Agric. Food Chem. 53, 2362-2370.

Jolliffe, I., Penny, K. 2002. Comparison of multivariate outlier detection methods - Authors response. J. Royal Statistics Soc. - Series D The Statistician 51, 396-397.

Jondreville C., Travel A., Besnard J., Feidt C. 2010. Intake of herbage and soil by free range laying hens offered a complete diet compared to a whole-wheat diet. XIIlth European Poultry Conference, Tours, France, 23-27 August

Enes, K.C. Stratford, J.A. Tidridge, P., Waterhouse, K. Johnston, A.E 1989. Polynuclear aromatic hydrocarbons in an agricultural soil: Long-term changes in profile distribution. Environ. Poll. 56, 337-351.

urjanz S., Feidt C., Pérez-Prieto L.A., Ribeiro Filho H.M.N., Rychen G., Delagarde R. 2012. Soil intake of lactating dairy cows in intensive strip-grazing systems. Animal 6 1350-1359.

Kaewkot, C., Ruangsuriya, J., Kreuzer, M., Jaturasitha, S. 2020. Carcass and meat quality of crossbreds of Thai indigenous chickens and Rhode Island Red layer chickens as compared with the purebreds and with broilers. Animal Prod. Sci. 60, 454-463.

Kaewmanee, T., Benjakul, S., Visessanguan, W. 2009. Changes in chemica composition, physical properties and microstructure of duck egg as influenced by salting. Food Chem. 112, 560-569.

Kelly, B.C., Gobas, F.A.P.C., McLachlan, M.S. 2004. Intestinal absorption and biomagnification of organic contaminants in fish, wildlife, and humans. Environ. Toxic. Chem. 23, 2324-2336.

Kerst, M., Waller, U., Reifenhäuser, W., Körner, W. 2004. Carry-over rates of dioxin-like PCB from grass to cow's milk. Organohalogen. Comp. 66, 2412-2415.

Kierkegaard, A., Asplund, L., de Wit, C.A., McLachlan, M.S., Thomas, G.O., Sweetman A.J., Jones, K.C. 2007. Fate of higher brominated PBDEs in dairy cows. Environ. Sci. Technol. 41, 417-423.

Kierkegaard, A., de Wit, C.A., Asplund, L., McLachlan, M.S., Thomas, G.O., Sweetman A.J., Jones, K.C. 2009. A mass balance of tri-hexabrominated diphenyl ethers in lactating cows. Environ. Sci. Technol. 43, 2602-2607.

Kohli J., Wyndham, C., Smylie, M., Safe, S. 1978. Metabolism of bromobiphenyls. Biochem. Pharm. 27, 1245-1249.

Kuroki, J., Nobuyuki K., Hidetoshi Y. 1986. High Affinity of 2,3,4,7,8 Pentachlorodibenzofuran to Cytochrome P-450 in the Hepatic Microsomes of Rats. Chemosphere 15, 731-38.

Lorenzi, V., Angelone, B., Ferretti, E., Galli, A., Tonoli, M., Donati, M., Fusi, F., Zanardi, G., Ghidini, S., Bertocchi, L. 2020. PCDD/Fs, DL-PCBs and NDF-PCBs, in Dairy Cows: Carryover in Milk from a Controlled Feeding Study. J. Agric. Food Chem. https://dx.doi.org/10.1021/acs.jafc.9b08180.

Lutz, R.J., Dedrick, R.L., Matthews, H.B., Eling, T.E., Anderson, M.W. 1977. Preliminary pharmacokinetic model for several chlorinated biphenyls in rat. Drug Metabolism Disposition 5, 386-396.

Malisch, R. 2000. Increase of the PCDD/PCDF-contamination of milk, butter and meat samples by the use of contaminated citrus pulp. Chemosphere 40,1041-1053.

Matthews, H.B., Dedrick, R.L. 1984. Pharmacokinetics of PCBs. Annual Review Pharm Toxic. 24, 85-103

McLachlan, M., Richter, W., 1998. Uptake and Transfer of PCDD/Fs by Cattle Fed Naturally Contaminated Feedstuffs and Feed Contaminated as a Result ofSewage Sludge Application. 1. Lactating Cows. Journal of Agricultural and Food Chemistry46, 1166-1172. doi:10.1021/jf970922u.

McLachlan, M.S., Thoma, H., Reissinger, M., Hutzinger, O. 1990. PCDD/F in an agricultural food chain Part 1: PCDD/F mass balance of a lactating cow. Chemosphere 20, 1013-1020.

McLachlan, M.S. 1993. Digestive tract absorption of polychlorinated dibenzo-p-dioxins dibenzofurans, and biphenyls in a nursing infant. Toxic. Applied Pharmacology 123 68-72.

Morck, A., Hakk, H., Orn, U., Wehler, E.K. 2003. Decabromodiphenyl ether in the rat: absorption, distribution, metabolism, and excretion. Drug Metab. Dispos. 31, 900-907. Ohtake, F., Baba, A., Takada, I., Okada, M., Iwasaki, K., Miki, H., Takahashi, S. Kouzmenko, A., Nohara, K., Chiba, T., Fujii-Kuriyama, Y., Kato, S. 2007. Dioxin receptor is a ligand-dependent E3 ubiquitin ligase. Nature 446, 562-566.

Olling, M., Derks, H.J.G.M., Berende, P.L.M., Liem, A.K.D., DeJong, A.P.J.M. 1991 Toxicokinetics of 8 C13-labeled polychlorinated dibenzo-p-dioxins and 13 dibenzo-pfurans in lactating cows. Chemosphere 23, 1377-1385.

Ounnas, F., Feidt, C., Toussaint, H., Marchand, Ph., Le Bizec, B., Rychen G., Jurjanz, S. 2010. Polychlorinated biphenyl and low polybrominated dephenyl ether transfer to milk in lactating goats chronically exposed to contaminated soil. Environ. Sci. Technol. 44 2682-2688

Parera, J., Abalos, M., Perez-Vendrell, A.M., Brufau, J., de Juan, F., Escribano, F., Abad, E., Rivera, J. 2008. Occurrence and bioaccumulation study of PCDD and PCDF from mineral feed additives. Chemosphere 73, S252-S260.

Pan, J., Gai, N., Tang, H., Chen, S., Chen, D., Lu, G., Yang, Y. 2014. Organochlorine pesticides and polychlorinated biphenyls in grass, yak muscle, liver and milk in Ruoergai high altitude prairie, the eastern edge of Qinghai-Tibet plateau. Sci. Tot. Environ 491-492, 131-137.

Petreas, M., Goldman, L.R., Hayward, D.G., Chang, R.R., Flattery, J.J., Wiesmuller, T., Stephens R.D., Fry, D.M., Rappe, C., Bergek S., Hjelt, M. 1991. Biotransfer and bioaccumulation of PCDD PCDFs from soil - controlled exposure studies of chickens. Chemosphere 23, 1731-1741.

Pirard, C., De Pauw, E. 2005. Uptake of polychlorodibenzo-p-dioxins, polychlorodibenzofurans and coplanar polychlorobiphenyls in chickens. Environ. Int 31, 585-591.

Prard, C. . De Pauw, E. 2006. Toxicokinetic study of dioxins and furans in laying chickens. Environment international, 32 , 466-469, doi:10.1016/j.envint.2005.10.005.

Piskorska-Pliszczynska, J., Mikolajczyk, S., Warenik-Bany, M., Maszewski, S., Strucinski, P. 2014. Soil as a source of dioxin contamination in eggs from free-range hens on a Polish farm. Sci. Tot. Environ. 466-467, 447-454

Richter, W. McLachlan, M.S. 2001. Uptake and transfer of PCDD/Fs by cattle fed naturally contaminated feedstuffs and feed contaminated as a result of sewage sludge application. 2. Non lactating cows. J. Agric. Food Chem. 49, 5857-5865.

Rose, M., Fernandes, A., Foxall, C., Dowding, A. 2012. Transfer and uptake of polychlorinated dibenzo-p-dioxins and furans (PCDD/Fs) and polychlorinated 
biphenyls (PCBs) into meat and organs of indoor and outdoor reared pigs. Food Additives and Contaminants 29, 431-448.

Sanford, P. 1992.Physiological Principles in Medicine: Digestive System Physiology.

Edward Arnold, London, UK.

Schuler, F., Schmid, P., Schlatter C. 1997. Transfer of airborne polychlorinated dibenzop-dioxins and dibenzofurans into dairy milk. J. Agric. Food. Chem. 45, 4162-4167.

Shih, S.J., Wang, IC, Wu, K.Y., Li, H.W., Wang, L.C., Chang-Chien, G.P. 2009. Uptake of polychlorinated dibenzo-p-dioxins and dibenzofurans in laying ducks. J. Environ. Sci. Health - Series A Toxic Hazardous Subst. and Environ Engin. 44, 799-807.

Shen, H.; Henkelman, B.; Rambeck, W.; Mayer, R.; Wehr, U.; Schramm, K. 2012. Physiologically based persistent organic pollutant accumulation in pig tissues and their edible safety differences: an in vivo study. Food Chemistry, 132, 1830-1835..

Slob, W., Olling, M., Derks, H.J.G.M., De Jong, A.J.P.M., 1995. Congener-specific bioavailability of PCDD/F and coplanar PCBs in cows: laboratory and field measurements. Chemosphere 31, 3827-3838.

Soine, P.J., Blanke, R.V., Guzellian, P.S., Schwartz, C.C. 1982. Preferential binding of chlordecone to the protein and high-density lipoprotein fractions of plasma from Humans and other species. J. Toxic. Environm. Health 9, 107-118.

Spitaler, M.; Iben, C.; Tausch, H. 2005. Dioxin residues in the edible tissue of finishing pigs after dioxin feeding. Journal of animal physiology and animal nutrition, 89, 65-71.

Stapelton, H.M., Alaee, M., Letcher, R.J., Baker, J.E. 2004. Debromination of the flame retardant decabromodiphenyl ether by juvenile carp (Cyprinus carpio) following dietary exposure. Environ. Sci. Technol. 38, 112-119.

Stevens, J.B., Gerbec, E.N., 1988. Dioxin in the Agricultural Food Chain. Risk Analysis 8, 329-335

Tao, S., Liu, W.X., Li, X.Q., Zhou, D.X., Li, X., Yang, Y.F., Yue, D.P., Coveney, R.M. 2009. Organochlorine pesticide residuals in chickens and eggs at a poultry farm in Beijing, China. Environ. Poll. 157, 497-502.

Thomas, G.O., Sweetman, A.J., Jones, K.C. 1999. Metabolism and body-burden of PCBs in lactating dairy cows. Chemosphere 39, 1533-1544.

Thorpe, S., Kelly, M.; Startin, J.; Harrison, N.; Rose, M. 2001. Concentration changes for 5 PCDD/F congeners after administration in beef cattle. Chemosphere, 43, 869-879.

Traag, W.; Kan, K.; Zeilmaker, M.; Hoogerbrugge, R.; van Eijkeren, J. 2004 Carry-over of dioxins and PCBs from feed and soil to eggs at low contamination levels, 77

Traag, W.A., Kan, C.A., van der Weg, G., Onsteng, C., Hoogenboom, L.A. 2006. Residues of dioxins (PCDD/Fs) and PCBs in eggs, fat and livers of laying hens following consumption of contaminated feed. Chemosphere 65, 1518-1525.

Tuinstra, L.; Roos, A.; Berende, P.; Rhijn, J.; Traag, W.; Mengelers, M. 1992. Excretion of polychlorinated dibenzo-p-dioxins and -furans in milk of cow fed on dioxins in the dry period. J. Agric. Food Chem. 40, 1772-1776.

Watanabe, M.; Kunisue, T.; Tao, L.; Kannan, K.; Subramanian, A.; Tanabe, S.; Iwata, H. 2010. Dioxin-like and perfuuorinated compounds in pigs in an indian open waste dumping site: toxicokinetics and effects on hepatic cytochrome p450 and blood plasma hormones. Environmental Toxicology and Chemistry, 29, n7, pp. 1551-1560. DOI: 10.1002/etc. 189

Wittsiepe, J.; Erlenkamper, B.; Welge, P.; Hack, A.; Wilhelm, M. 2007. Bioavailability of PCDD/F from contaminated soil in young Goettingen minipigs. Chemosphere, 67, S355-S364, doi:10.1016/j.chemosphere.2006.05.129

\section{Acknowledgements}

The authors thank warmly for the French-Kazakh
scholarship Abaï-Verne supporting this PhD project
as well as Thomas Schulze for English
proofreading.

